\title{
BENEFICIAL EFFECTS OF NON-CHEMICALLY GROWN TRADITIONAL RICE/ RICE BASED FUNCTIONAL FOOD (NGTRF) IN NUTRITIONAL MANAGEMENT OF NAFLD AND DIABETES MELLITUS
}

\author{
R.D.S.S. Wickramasinghe ${ }^{1 *}$, K.S. Dahanayaka ${ }^{2}$, M.P. Batagoda ${ }^{3}$, G.V.C.P. de Silva ${ }^{4}$, \\ P. Senanayake ${ }^{5}$, J.S.A. Pathirana ${ }^{6}$, S. Sonnadara ${ }^{7}$ and S.P. Saman Kumara ${ }^{8}$ \\ ${ }^{1}$ District General Hospital, Gampaha, Sri Lanka \\ ${ }^{2}$ Food Production National Programme, Presidential Secretariat, Sri Lanka \\ ${ }^{3}$ District General Hospital, Matara, Sri Lanka \\ ${ }^{4}$ Provincial Ayurveda Hospital, Galle, Sri Lanka \\ ${ }^{5}$ Hela Suwaya Trust Fund, Sri Lanka \\ ${ }^{6}$ Ayurveda Central Dispensary, Kurundugahahathapma, Sri Lanka \\ ${ }^{7}$ Dissanayake Ayurveda Hospital, Galle, Sri Lanka \\ ${ }^{8}$ Ayurveda Central Dispensary, Nawungala, Sri Lanka
}

\begin{abstract}
Non-communicable diseases (NCD) are commonly associated with Non-alcoholic Fatty liver/Non-alcoholic Fatty Liver Disease (NAFL/NAFLD) for which no drugs or specific food are available either to control or to cure. We encounter promising results with NGTRF in nutritional Management of NAFLD and Diabetes. Objective is to compare the Effect of using NGTRF over Routine Western Management (RWM) and Hela Nila Wedakama (HNW). patients with NCD, including metabolic syndrome, are prescribed NGTRF (produced by Hela Suwaya) and followed up. The five therapeutic categories are (1) RWM alone (2) NGTRF alone (3) NGTRF+RWM (in Galle) (4). NGTRF+RWM (in Gampaha) (5) NGTRF+RWM+HNW. According to clinical, biochemical and radiological profiles, majority of category 2, 3, 4 and 5 are either controlled or cured effectively and sustainably compared to category 01. Preliminary evidence shows that effectiveness and sustainability of prescribing NGTRF is better. According to "Hela Suwaya" knowledge, genetic basis of food (conventional vs traditional) and agronomic practices should be strongly considered while prescribing food. Traditional rice grown with toxin free Hela Suwaya "Hela Govithena" technology improves the micronutrient, prebiotic, probiotic and antioxidant profiles of food. Agrochemical farming reduces these parameters by reducing soil $\mathrm{pH}$ and biota. Functional foods produced by Hela Suwaya post-harvest food technology (such as rice-based porridge) will further improve these nutritional profiles. The resulting optimization of the disturbed liver function is the key factor behind this beneficial effect on whole NCD spectrum. This is observed as cured or reduced NAFL/NAFLD. We have already planned Controlled clinical trials for further confirmation. Proper food-based intervention is therefore strongly suggested.
\end{abstract}

Keywords: NCD, Non-Alcoholic Fatty Liver Disease, Traditional Rice, Functional foods

\section{Introduction and Background}

\section{Non-communicable diseases and Non-Alcoholic Fatty Liver Disease}

Non-communicable diseases (NCD) are increasingly being reported globally in all age groups (WHO, 2014). Diabetes, hypertension, ischemic heart diseases, cancers etc. are amongst the most frequent. Metabolic syndrome (MS), characterized by hypertension, insulin resistance (impaired glucose tolerance or diabetes), hyperlipidemia and central obesity, represents the major risk factor for most of these NCD (Tarantino and Finelli, 2013). Diabetes mellitus is a chronic, progressive, incompletely understood metabolic condition chiefly characterized by hyperglycemia (Chaudhury et al., 2017). Non-alcoholic fatty liver diseases (NAFLD) is considered to be the hepatic manifestation or even a predictor of the MS (Marchesini et al., 2001, Ekstedt et al., 
2006, Puri and Sanyal, 2012, Fotbolcu and Zorlu, 2016). US National Institute of Diabetes and Kidney Diseases defines NAFLD as a condition in which fat builds up in the liver which is not caused by the heavy alcohol use. It is classified as Simple Fatty Liver (SFL) and Non-Alcoholic Steatohepatitis (NASH). SFL has either no or little inflammation whereas NASH is associated by inflammation and fibrosis owing to hepatocellular damage (Puri and Sanyal, 2012, Siriwardana et al., 2013). NASH might be complicated by either cirrhosis and /or hepatocellular carcinoma (Puri and Sanyal, 2012). NAFLD is said to be the commonest entity of liver diseases and around $25 \%$ of global population is affected. Around $7-30 \%$ of them are estimated to be having NASH (Younossi et al., 2016). The prevalence of NAFLD in western countries is estimated to be between 24-42\%. In Colombo, Sri Lanka, people who undergo Liver biopsy for raised liver enzymes and children attending to the obesity clinics are reported to be having NAFLD in 35\% and 18\% respectively (Amarapurkar et al., 2007).

"Hela Suwaya" is an organization which is operated based on knowledge pertaining to Sri Lankan indigenous medicine, agriculture and food science. This knowledge is acquired in relation to practices of Buddhism. "Hela Suwaya" is of strong opinion that above-mentioned NCD and NAFLD should specifically be considered together in working out the pathophysiologic basis of NAFLD and NCD.

According to the statistics, Obesity and Type 2 Diabetes are associated in 80-90\% with NAFLD (Heidari and Gharebaghi, 2017). Now the trend is gradually changing towards the increasing prevalence of NAFLD even in normal weight children (Kim and Kim, 2017), which is an eye opener for us to think about NAFLD and NCD appearing in conventionally low risk categories as well. Over $40 \%$ women of child baring age with PCOD are co-existent with NAFLD. MS and Higher lipid profiles are also increasingly being associated with NAFLD (Vassilatou et al., 2015). Therefore, it could be generally stated that NAFLD is a common association of NCD and at present, its prevalence clearly exceeds that of all NCDs. Therefore, pathophysiologic role of NAFLD in causing or at least contributing to the NCD should be strongly considered. Increasing prevalence of NAFLD among $10 \%$ in US children (amounts to 30 million) highlights the importance of implementing early interventions (Sundaram, 2012, Mann et al., 2015).

No proven pharmacological or specific food based intervention has yet been available for NAFLD (ALF, 2017). Conventional food based interventions meant for NCD management at present, especially in Sri Lankan setup, include red rice based food staples, cutting down of refined sugar and salt, minimizing foods with saturated fats, promoting foods with mono unsaturated fats and omega 3 fatty acids, advice on high fiber and low-calorie diet etc. (Withana, 2014). Available scientific evidence does not support that artificial supplementations (of micronutrients, antioxidants, probiotics etc) are as good as food-based interventions. For example, American cancer society has stated that no scientific proof has yet been available to say that phytochemical supplementations are as effective as consuming fruits, vegetables, beans, and grains as far as long-term health is concerned (Dillard and German, 2000, Webb, 2013). RWM of NCD include above dietary management with exercise and drug treatment. Though the existing pharmacological intervention for NCD is only targeted for controlling the diseases, it is not meant to cure them. Therefore, the term "Management" is used instead of "Cure" as far as the treatment of NCD is considered. Likewise, a therapeutic vacuum has been existing with regards to the definitive treatment of NAFLD as well as NCD.

\section{Proposed Scientific Basis for Disturbance of Liver metabolism, NAFLD, and NCD}

Gastro intestinal system is the first system which deals with the metabolism of food. Gut carries out the Digestion and Absorption of the ingested food. Hela Suwaya knowledge further highlights the fact that apart from these two processes, it involves production of micronutrients, mediation of immunity and detoxification of ingested toxins as well. All of them are enzymatically and hormonally regulated, and are highly dependent on micronutrients, fibers and microbiota (O'Connor, 2013, Chen, 2015, Dearing and Kohl, 2017, Wu and Tian, 2017). Liver is the primary organ of the body which detoxifies the toxins entering in to the body using series of interrelated specialized enzymatic pathways. These reactions are also highly nutrient dependent, and these 
nutrients include vitamins, minerals, plant nutrients and essential amino acids. Liver is also the main organ in the body which maintain the balance of carbohydrate, proteins, lipids, micronutrients etc. (Canbay et al., 2007, Chavez-Talavera et al., 2017). It regulates the major endocrine functions such as of insulin, reproductive hormones etc. Maintaining the immunity is also one of its major functions. This signifies the fact that the liver (and gut) are naturally be the first and most sensitive organs which respond to the major fluctuations of the profiles of toxins, nutrients and pathogens entering the body. According to the literature, though our DNA and genetics haven't changed much over the past century, over 89,000 new chemicals including agrochemicals have been introduced to our environment and 1500 new chemicals are added every year without knowing their long term sequalae in human body (Bergman, 2017). Liver (and gut) have therefore become the dumping ground for all these toxins and it runs with the cumulative burden of "Exhaustive detoxification Process". As a result, the deficiency of the micronutrients (and plant nutrients), fiber and gut microbiota cause digestion and absorption of food, immunity, endocrine function, regulation of nutrients and detoxification process to be jeopardized. Being the designated organ to deal with the series of xenobiotic transformation reactions, liver is naturally being the most vulnerable organ for xenobiotic induced cellular damage caused by suboptimal nutritional status. It creates the vicious cycle of cellular damage and resulting derangement of liver function, which forms the basis of NAFLD and NCD.

\section{Proposed Food based mechanism for NCD and NAFLD, by "Hela Suwaya"}

"Hela Suwaya" categorically proposed how the conventional food pattern is contributed to this vicious process leading to increasing incidence of NAFLD, MS and thereby the NCD. For this scenario to be explained, it is worth considering the profile of crop variety, agronomy, food processing, and culinary preparation of present day conventional food/ food commodities. Sri Lankan Traditional Rice Varieties (SLTRV), are found to be having comparatively high nutritional values compared to new rice varieties. They include proteins, micronutrients (Vitamins and minerals), fibers (Prebiotics), microbiota (probiotics) and bioactivities like antioxidant, anti-inflammatory, antidiabetic, anticancer etc. This clearly indicates how the burden of malnutrition is created by gradual deviation from traditional food staples. Unlike in the past (prior to 1950), at present, most of the food crops are produced through application of agrochemicals (pesticides, fertilizer, hormones etc.) and by using seeds which are improved (artificially domesticated), hybridized, or gene modified to produce high yield through agrochemical dependency. This agronomic practice will not only cause destruction of soil micro and macro biota, but also pollutes the soil with pesticide residues and heavy metals (contained in agrochemicals either as pollutants or by means of adulteration) as well. This mechanism hinders soil nourishment and bioremediation of toxins facilitated by soil biota. This causes food crops to be deprived of its nutritional profile (especially micronutrients) and to be polluted by toxins (Zacharia, 2011, Acharya, 2013). Alternatively, crops produced through organic farming have clearly shown to be having higher micronutrient and phytochemical profile compared to that of chemical farming. Hela Suwaya further states that toxin induced disturbance of insect pollination will prevent the production of fiber profile in the food crop (Klatt et al., 2014, Viviane C. Pires1, 2014). Apart from that, lack of food diversity, application of artificial chemical food processing methods (including blending instead of traditionally used pounding) and improper culinary practices (such as deviating away the traditional culinary preparations and improper spicing of food) collectively add to the burden of sub optimal nutritional status in the community. Furthermore, consumption of such food (having pollutants and less fiber) also disturbs the essential natural gut microflora leading to deficiency in food digestion, micronutrient production, detoxification, nutrient absorption, and gut immunity which are induced/ facilitated by them (Parnell and Reimer, 2012, O'Connor, 2013, Tidjani Alou et al., 2016). This basically explains how the contribution of present food pattern forms the basis leading to disturbance of liver and gut function and thereby NAFLD and NCD (Kosiewicz et al., 2011, Festi et al., 2014). 


\section{Food based intervention by "Hela Suwaya" - The definitive solution for NAFLD/NCD}

Varietal difference of crops (i.e. whether traditional or modern), Agronomic practices, method of processing etc. are not considered together at all in the conventional nutritional practice at present. This is explained by the absence of wholistic understanding about the concept of "food" among the present-day health care givers, nutritionists, agriculturists, food technologists, policy makers etc. Hela Suwaya knowledge simply highlights the very fact that the "Nutrition begins from the field". In addition, Hela Suwaya, upon tracing back to the history of origins of both allopathic and Ayurvedic medicine, has clearly found that the therapeutics pertaining to prevention and cure of diseases described in both disciplinaries are centered mainly on food-based interventions. This fact has clearly been stated by the forefathers of both allopathy and Ayurveda, namely Hippocrates and Vāghbhata respectively.

Based on the above knowledge and being driven by the urge to fill the aforementioned therapeutic vacuum, Hela Suwaya has started producing traditional rice varieties since 2009 using herbal formulae instead of agrochemicals. Non-chemically grown Traditional Rice based Functional food (NGTRF) is a porridge variety produced by Hela Suwaya based on its knowledge on food technology. The nutritional as well as functional analysis conducted in accredited laboratories have clearly demonstrated that this 'functional food' is of marked nutritional and functional value compared to the traditional rice alone. Several Sri Lankan traditional spices and green leaves which are having proven health claims are also used in the processing of this medicinal porridge formulae. Apart from the food-based interventions, Hela Suwaya has been practicing a disciplinary of Medicine called "Hela Nila Wedakama", in which the disease condition is understood by feeling pulse of the patient. The treatment is practiced by application of a paste, made by pounding together of parts of medicinal herbal plants taken at specific ratios (depending on the illness), on "Active Points" on the skin. This is meant to correct the disrupted physio-chemical balance in the body through hormonal regulation.

Effect of these Sri Lankan traditional rice/food based functional food interventions on the clinical management of NCD including NAFLD has not yet been carried out. Initially, isolated cases have been reported to be having beneficial effects. Therefore, as the initial step, much wider study was started at multi-center level as a case study for the purpose of generating at least preliminary evidence as to the beneficial effect of NGTRF. This case study includes provisional results obtained from the patients who are still attending to the above clinics. Controlled clinical trials are also been designed and even commenced to confirm this beneficial effect of NGTRF in a more scientific way. Hela Suwaya initiated this as the door step towards reinvention of neglected and undermined traditional food-based intervention which is more sustainable and socio-economically acceptable to Sri Lankan community. Hela Suwaya strongly believes that it had been the basis of the longevity of our ancestors. This is evidently mentioned in the first ever encyclopedia of the history called "Naturalis Historia" written by Pliny the Elder, a great Roman philosopher in the $01^{\text {st }}$ century A.C. It is worth mentioning here that, he has clearly expressed as the ending few wards of its $24^{\text {th }}$ chapter named "Taprobane" (the ancient Sri Lanka) as follows, "these people look upon a hundred years as a comparatively short life, thus much have we learnt respecting Taprobane".

\section{Objective}

\section{General Objective}

To compare the Effect of using NGTRF over conventional treatment modes

\section{Specific objectives}

2.2.1. To study the effect of Routine Western Management (RWM) in the dietary intervention of diabetes

2.2.2. To study the effect of NGTRF alone or with RWM in the dietary intervention of NAFLD 
2.2.3. To study and compare the effect of various combinations of NGTRF, RWM and HNW in diabetes

2.2.4. To study how the western drug treatment could be gradually changed while diabetic patients are on combined treatment of NGTRF, RWM and HNW

\section{Methodology}

Traditional rice varieties from which NGTRF is made of are cultivated while being monitored by specially trained personnel. Based on the understanding of the concept of "Nutrition begins from the field" the method of cultivation is also included under the methodology section.

\section{Cultivation Sri Lankan Traditional Rice Varieties (SLTRV) by echo-friendly farming}

SLTRV are cultivated according to "Hela Suwaya" Non-Chemical Farming Technology called "Hela Govithena" (in Sinhalese) using Herbal Formulae called "Govithenata Aushadha" (in Sinhalese). They are made of mixture of herbs and animal feces (cow dung etc.) taken at a specific ratio (as several Formulae). They are subjected to natural processing including pounding (instead of blending), mixing with water, fermentation etc. They are applied Periodically to the Field as the sole application and no Pesticides, Fertilizer or hormones are used at all. No chemicals used to preserve paddy/rice. This technology is fundamentally different from the conventional "organic" farming. The resultant rice produce was analyzed to be of no agrochemical residues.

\section{Production of NGTRF}

NGTRF are made as porridges out of 58 ingredients including specific mixtures of SLTRV, spices, green leaves and edible herbs (Table 01). Special Processing methods used includes frying, pounding, fermenting etc. (using Blender is totally discouraged). Guidelines as to the Post Harvest Food Technology (PHFT) has been clearly given in "Hela Suwaya" discipline of indigenous medicine called "Hela Nila Wedakama" (based on Buddhist spiritual background). This includes traditional Sri Lankan food crops, technology pertaining to food processing, and how these preparations are altered with regards to variety and method of processing to get its maximum remedial action in par with the toxin profile associated with the present-day food pattern. These porridge formulae are completely vegetarian and do not contain any artificial/chemical preservatives, colorings, flavor enhancers etc.

Table 01: Constituents of NGTRF

\begin{tabular}{|c|c|c|c|c|}
\hline \multirow{2}{*}{ SLTRV } & \multicolumn{3}{|l|}{ Pre-prepared } & \multirow{2}{*}{ Added fresh } \\
\hline & \multicolumn{2}{|c|}{ Herbals/Spices (Botanical names) } & Others & \\
\hline $\begin{array}{l}\text { Kalu heenati } \\
\text { Pachchaperumal } \\
\text { Madathawaalu } \\
\text { Kahawanu } \\
\text { Batapolal } \\
\text { Kuruluthuda } \\
\text { Malakada }\end{array}$ & $\begin{array}{l}\text { Vigna Radiata } \\
\text { Brassica juncea } \\
\text { Musa spp. } \\
\text { Hemidesmus indicus } \\
\text { Plectranthus zeylanicus } \\
\text { Desmodium triflorum } \\
\text { Trigonella foenum-graecum } \\
\text { Murraya koenigii } \\
\text { Syzygium aromaticum } \\
\text { Sesamum spp. } \\
\text { Caryota urens } \\
\text { Cinamomum verum } \\
\text { Coriandrum sativum } \\
\text { Cephalandra indica } \\
\text { Piper nigrum } \\
\text { Centella asiatica } \\
\text { Costus speciosus } \\
\text { Citrus aurantiifolia } \\
\text { Asteracantha longifolia } \\
\text { Passiflora edulis }\end{array}$ & $\begin{array}{l}\text { Cicer arietinum } \\
\text { Cocos nucifera } \\
\text { Aerva lanata } \\
\text { Abelmoschus esculentus } \\
\text { Aegle marmelos } \\
\text { Manihot esculenta } \\
\text { Foeniculum vulgare } \\
\text { Moringa oleifera } \\
\text { Cassia auriculata } \\
\text { Allium cepa L. } \\
\text { Pandanus amaryllifolius } \\
\text { Raphanus spp. } \\
\text { Artocarpus heterophyllus } \\
\text { Cardiospermum halicacabum } \\
\text { Peucedanum graveolens } \\
\text { Allium sativum } \\
\text { Cuminum cyminum } \\
\text { Asparagus racemosus } \\
\text { Osbeckia octandra }\end{array}$ & $\begin{array}{l}\text { Ghee } \\
\text { Bee honey } \\
\text { Sago }\end{array}$ & $\begin{array}{l}\text { Radish } \\
\text { Pumpkin } \\
\text { Beans } \\
\text { Carrot } \\
\text { Radish } \\
\text { Pennywort } \\
\text { Coconut } \\
\text { Mustard } \\
\text { Garlic } \\
\text { Curry leaves } \\
\text { Table salt }\end{array}$ \\
\hline
\end{tabular}




\section{Preparation of NGTRF}

Patients are instructed to prepare and drink the NGTRF (porridge) daily as a home-based intervention. Culinary preparation or cooking of NGTRF is done according to the written instructions provided with pack of NGTRF, by using contained rice/flour mixture and the pre-prepared packet of spices supplied within the pack in separation. It requires few ingredients including coconut milk to be added fresh as instructed.

\section{Selection criteria and exclusion criteria for this case study}

Following categories of patients were selected based on their findings of the first clinic visit

3.4.1. Patients (with or without written records of the diagnosis as to Diabetes Mellitus) with high blood sugar more than $125 \mathrm{mg} / \mathrm{dl}$ and are either on or not on RWM

3.4.2. Patients who are registered in ayurvedic clinic with the diagnosis of diabetes mellitus according to Ayurveda and having symptoms of diabetes. They were either on or not on ayurvedic treatment or RWM

3.4.3. Pre-diabetic patients whose FBS were ranging between 110 and $125 \mathrm{mg} / \mathrm{dl}$ (and were not on drugs)

3.4.4. NAFLD patients either on RWM (for accompanying NCDs) or not on any treatment

Above cases who had adequately adhered to treatment and advise and were available for regular follow up for a period of 01 month to 16 months were selected for this case study.

3.5. Patients were interviewed, intervened and followed up clinically (with symptoms and signs), biochemically [with Fasting Blood Sugar (FBS)] and radiologically (with Ultrasound scan) by qualified doctors in the field of Ayurveda and allopathy.

\section{Intervention regimens and study locations}

After obtaining informed consent NGTRF was prescribed at least one cup (amounts to 200ml) daily, either as the sole therapy or as a supplementation as follows,

3.6.1. Patients who were either on or not on Ayurvedic treatment or RWM and who were attending to four (04) Ayurvedic Clinics in Pitigala, Karandeniya, Akmeemana and Yakkalamulla divisional secretariats of Galle district, Sri Lanka. Seventy-four (74) patients have been selected altogether.

3.6.2. Patients who were on Oral Hypoglycemic Drugs (OHD) and Insulin, and who were refractory to OHD were referred to Medical Nutrition Clinic of District General Hospital, Gampaha, Sri Lanka. Total number of patients selected were 61 .

3.6.3. Patients who were on RWM and who were started on HNW following registration at Hela Suwaya treatment center, Pittugala, Sri Lanka. At Hela Suwaya "Hela Nila Wedakama" clinic, patients with chronic kidney disease and cancers are regularly followed up. Among these patients, blood sugar control of patients with diabetes were studied. End stage renal disease and end stage cancer patients were excluded as those disease states may affect the blood sugar levels in unpredictable ways. Selected number of patients were 18. NGTRF $(200 \mathrm{ml})$ was given twice a day for all patients and were regularly followed up in every other week. In "Hela Nila Wedakama, the herbal preparation was applied daily, on special "Nila" (active) points on the skin and kept for specified time duration per day. All these patients were treated while they are being continued on antidiabetic drugs. Antidiabetic drug doses were subjected to dose adjustments from the HNW clinic accordingly. 
3.6.3. Sample of patients who were on RWM with antidiabetic drugs but have not taken NGTRF were also selected

When all these study regimens are taken together, five treatment categories were present as follows.
(1) RWM alone
(2) NGTRF alone
(3) NGTRF+RWM (in Galle)

(4) NGTRF+RWM (in Gampaha)

(5) $\mathrm{NGTRF}+\mathrm{RWM}+\mathrm{HNW}$

\section{Results}

Signs and symptoms changed in those who are on Category no. 2-5

Symptoms and signs (clinical features) had been assessed, followed up and documented in 56 patients. Amongst the symptoms, Numbness of the hands and foot, body weakness, increased frequency of micturition, excessive sleepiness, joint pains, laziness, excessive thirst, abdominal fullness, poor vision, excessive sweat, constipation, loss of appetite and regurgitation are the most frequent. General clinical condition of all the patients of category 2, 3, 4 and 5 were improved. In clinical feature count, $87 \%$ and $73 \%$ of the symptoms and signs were either improved or cured in patients who were on NGTRF only (Category 2) and NGTRF+RWM (Category 3 and 4 ) respectively (Chart no.01). Among 18 patients who had undergone NGTRF+RWM+HNW (Category 5), 98\% of the clinical features were either improved or cured.

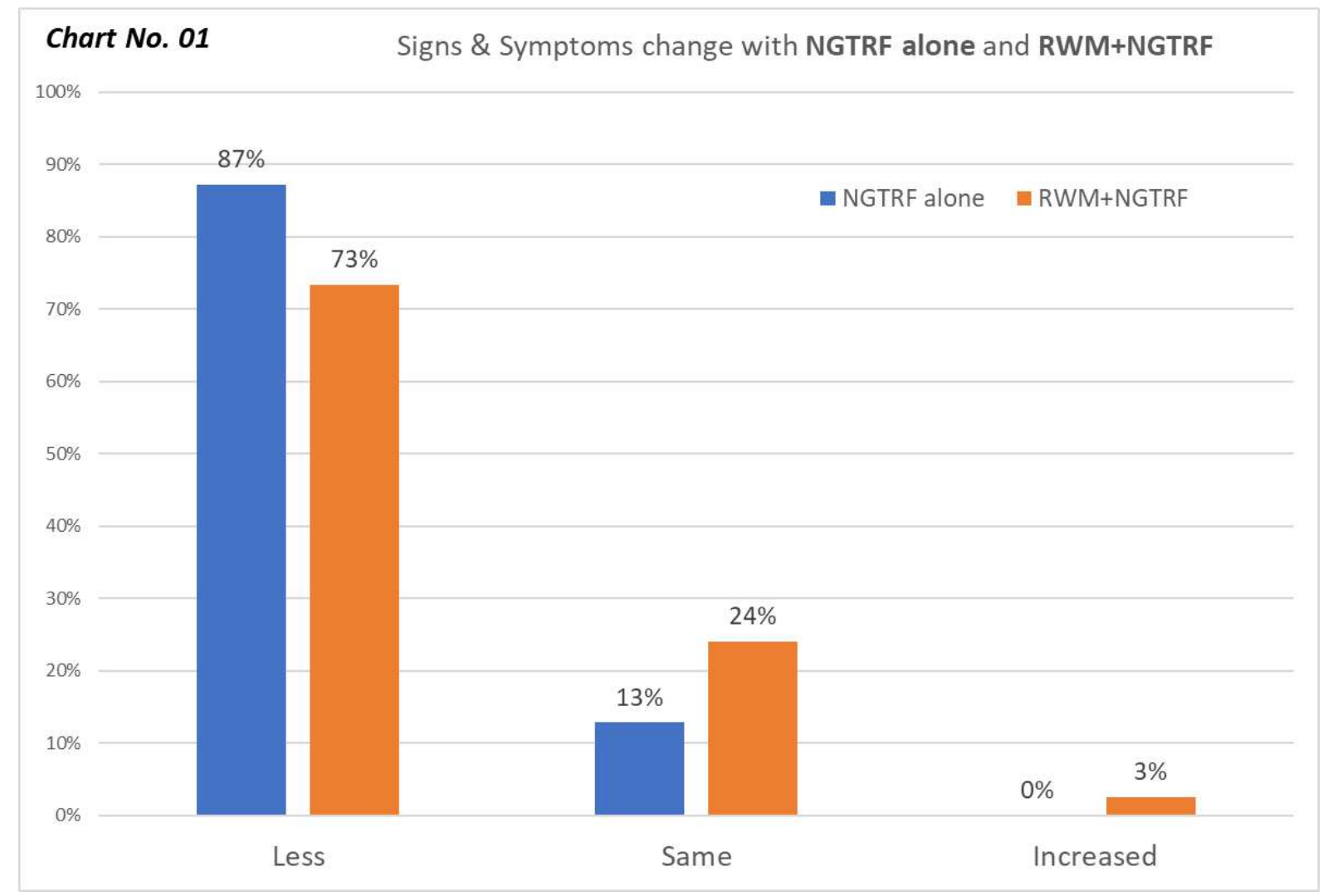




\section{NAFLD patients who are treated with NGTRF with or without RWM}

All the patients (attending to Medical nutrition clinic of District General Hospital Gampaha, Sri Lanka) who were on NGTRF alone or with RWM (for other NCDs) are either improved or cured within 011/2 to 091/2 months period. Majority (09 out of 13) of them were on NGTRF alone. (Table 02)

Table 02. Fatty liver status of the patients on NGTRF alone or with RWM

\begin{tabular}{|c|c|c|c|c|c|c|}
\hline Patient & Age (Years) & Gender & $\begin{array}{l}\text { Fatty Liver(FL) Grade } \\
\text { and Hepatomegaly(HM) }\end{array}$ & $\begin{array}{l}\text { Therapeutic } \\
\text { Category }\end{array}$ & $\begin{array}{l}\text { Duration on } \\
\text { NGTRF } \\
\text { (months, weeks) }\end{array}$ & $\begin{array}{l}\text { Result } \\
\text { FL Grade } \\
(0=\text { No FL })\end{array}$ \\
\hline 1 & 12 & $\mathrm{~F}$ & 2 & NGTRF alone & $7 \mathrm{~m} \mathrm{3wk}$ & 0 \\
\hline 2 & 9 & $\mathrm{~F}$ & $2+\mathrm{HM}$ & NGTRF alone & $5 \mathrm{~m}$ & 0 , No HM \\
\hline 3 & 9 & M & 2 & NGTRF alone & $4 \mathrm{~m} \mathrm{1wk}$ & 1 \\
\hline 4 & 12 & $\mathrm{~F}$ & $2+\mathrm{HM}$ & NGTRF alone & $4 \mathrm{~m} 2 \mathrm{wk}$ & 0, No HM \\
\hline 5 & 8 & M & 1 & NGTRF alone & $8 \mathrm{~m}$ & 0 \\
\hline 6 & 32 & $\mathrm{M}$ & 3 & NGTRF alone & $8 \mathrm{~m}$ & 1 \\
\hline 7 & 34 & $\mathrm{~F}$ & 3 & NGTRF alone & $4 \mathrm{~m}$ & 0 \\
\hline 8 & 18 & $\mathrm{~F}$ & 2 & NGTRF alone & $7 \mathrm{~m} 2 \mathrm{wk}$ & 1 \\
\hline 9 & 11 & $\mathrm{M}$ & 1 & NGTRF alone & $9 \mathrm{~m} 2 \mathrm{wk}$ & 0 \\
\hline 10 & 48 & $\mathrm{~F}$ & 2 & RWM + NGTRF & $1 \mathrm{~m} 2 \mathrm{wk}$ & 0 \\
\hline 11 & 12 & $\mathrm{~F}$ & 2 & RWM + NGTRF & $6 \mathrm{~m}$ & 1 \\
\hline 12 & 13 & $\mathrm{~F}$ & 2 & RWM + NGTRF & $4 \mathrm{~m} \mathrm{1wk}$ & 0 to 1 \\
\hline 13 & 27 & $\mathrm{~F}$ & 2 & RWM + NGTRF & $4 \mathrm{~m} 2 \mathrm{wk}$ & 1 \\
\hline
\end{tabular}

\section{Diabetic/prediabetic Patients who were treated with RWM alone (Graph 01,02,03)}

Among the patients who had been treated in Gampaha with only RWM, all the patients in the range of 70-125 $\mathrm{mg} / \mathrm{dl}$ at the onset, were gradually deteriorated and were unable to reach $<126 \mathrm{mg} / \mathrm{dl}$ range at the end of follow up. Four $(50 \%)$ out of eight patients in $126-180 \mathrm{mg} / \mathrm{dl}$ range were improving though all were above target range at the end. Ten $(83.33 \%)$ out of 12 patients in the $>180 \mathrm{mg} / \mathrm{dl}$ range has been improving while one of them was going in to the range of hypoglycaemia once; but at the end, all of them were above $125 \mathrm{mg} / \mathrm{dl}$ limit. (Desirable glycemic range, $70-125 \mathrm{mg} / \mathrm{dl}$, is shown in the graph with two horizontal dash lines) 
Proceedings of the International Conference on Nutritional and Genetic Epidemiology, Vol. 1, 2017, pp. 20-47

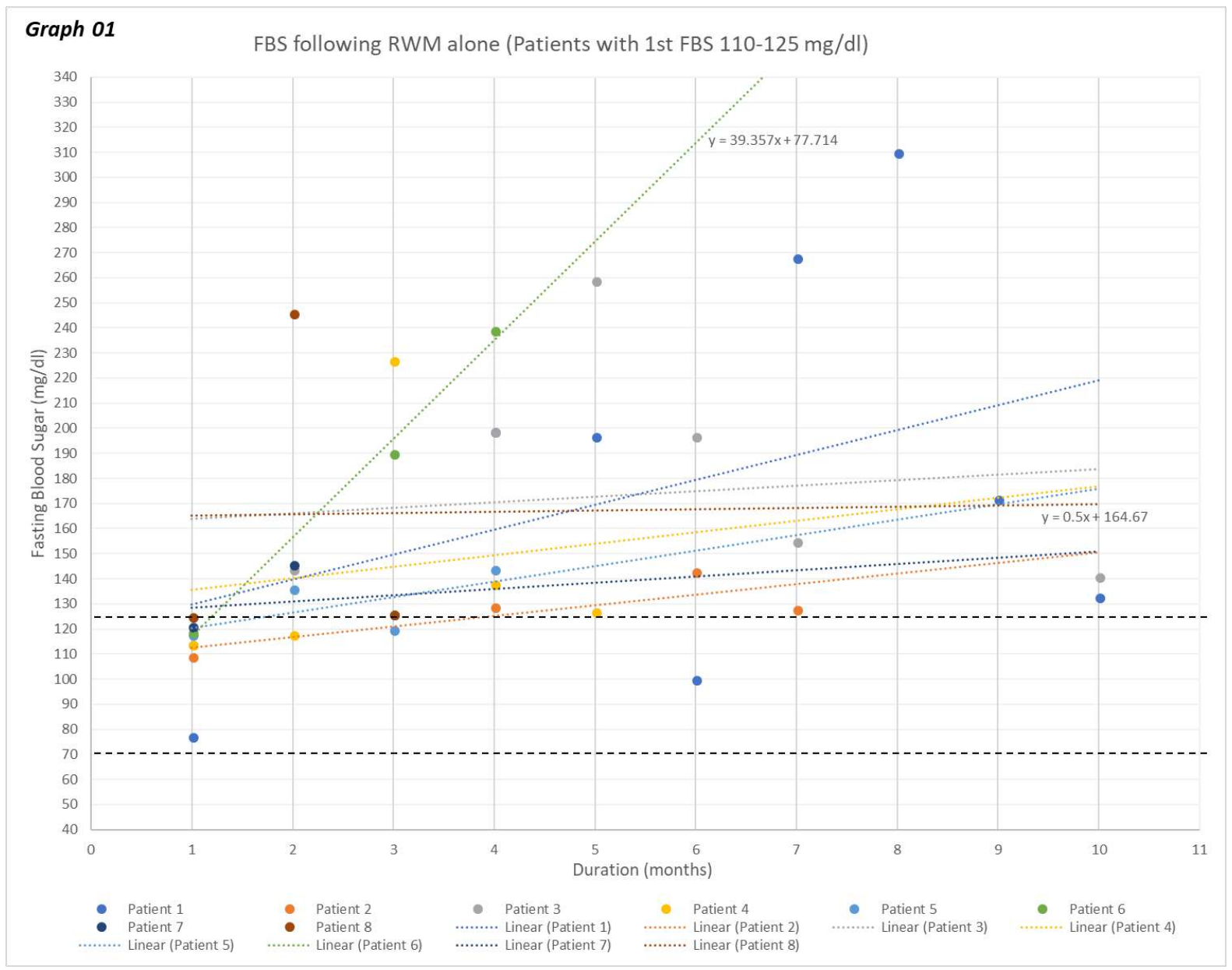

\section{Graph 02}

FBS following RWM alone (Patients with 1st FBS $126-180 \mathrm{mg} / \mathrm{dl}$ )

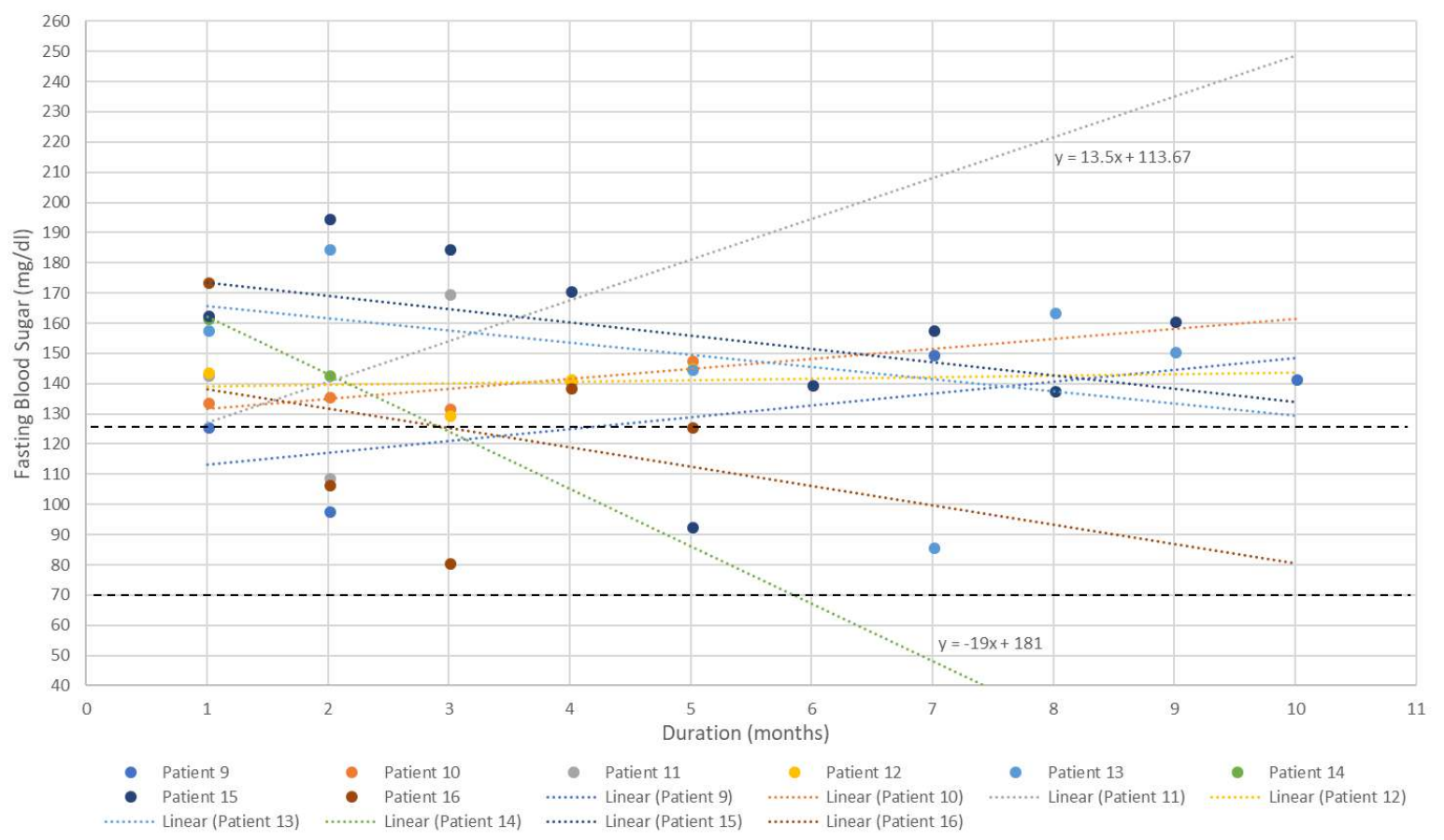




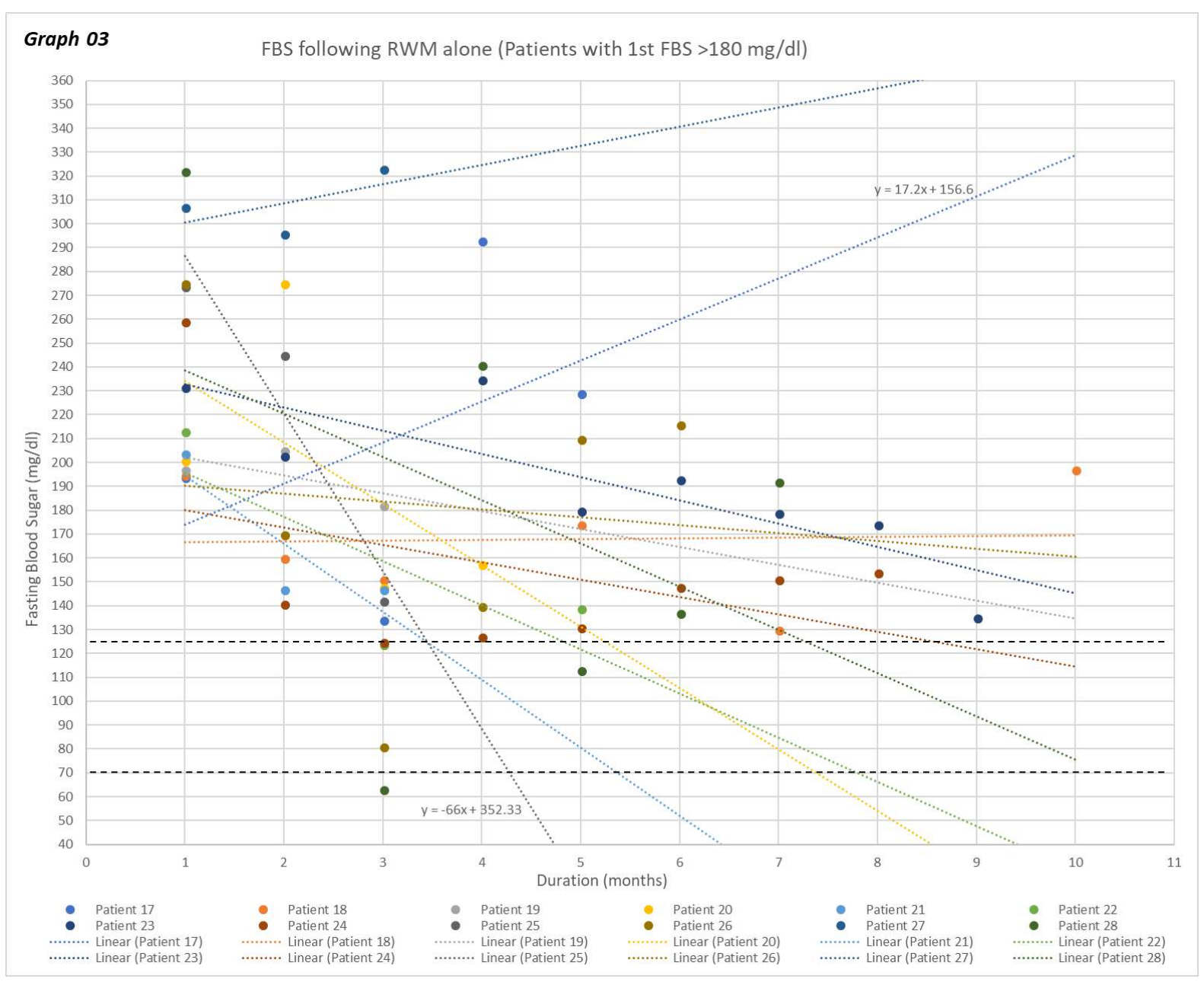

\section{Diabetic/prediabetic Patients who were treated with NGTRF alone (Graph 04,05,06)}

Majority (90.47\%) of patients attending to Clinics in Galle, who were either prediabetics or diabetics (FBS ranged from $111 \mathrm{mg} / \mathrm{dl}$ to $305 \mathrm{mg} / \mathrm{dl}$ at the first visit), getting NGTRF alone (Category 1) had improved their glycemic control. None of them went in to clinical hypoglycemic state or FBS less than $70 \mathrm{mg} / \mathrm{dl}$ despite the gradual reducing trend of glycemic status. 18 out of $21(85.7 \%)$ patients were able to manage FBS levels within desired range at the end. Gradient of reducing trend of FBS was positively corelated with the starting FBS status. 
Graph 04 FBS following NGTRF alone (Patients with 1st FBS $110-125$ mg/dl)

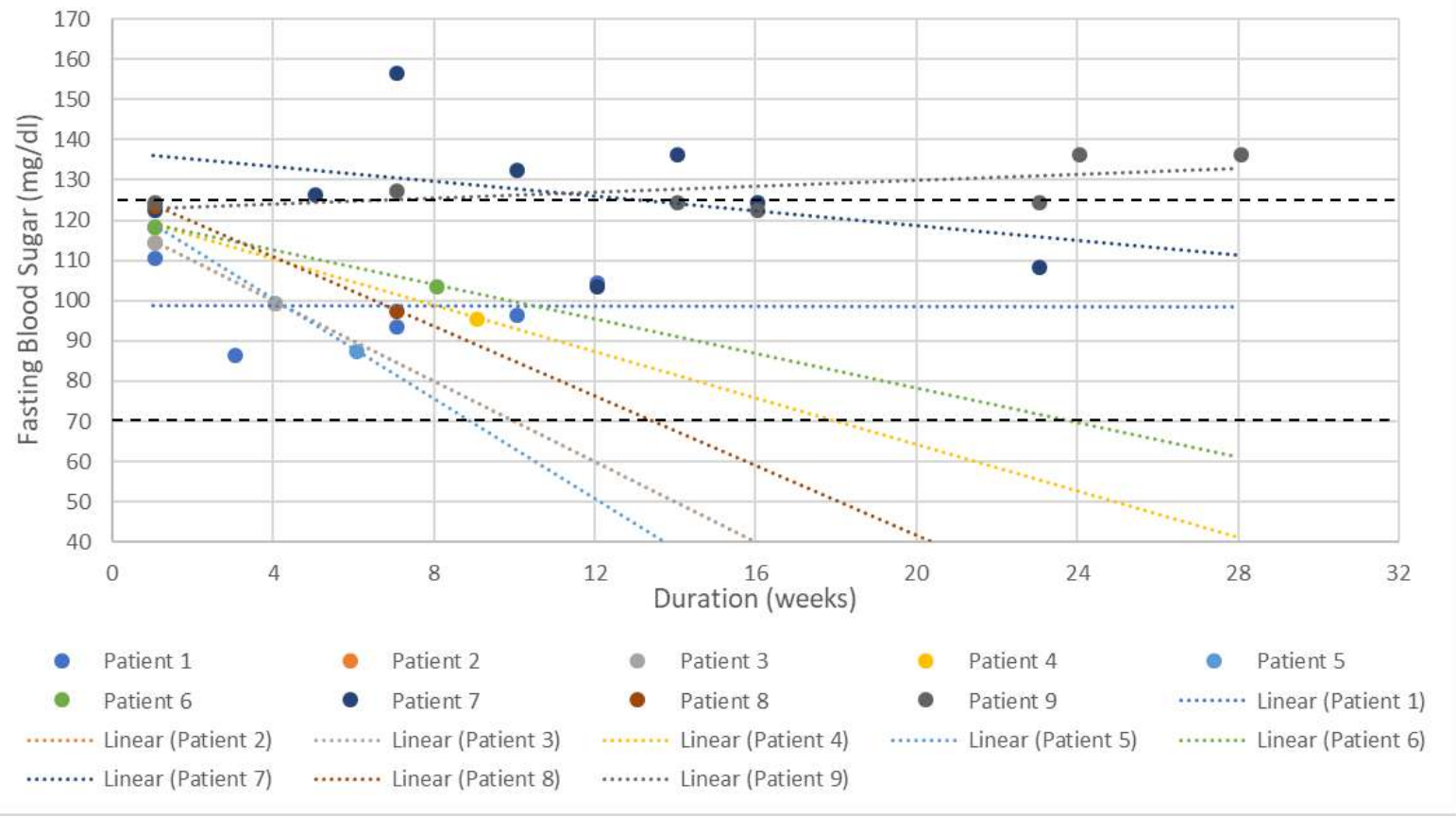

\section{Graph 05}

FBS following NGTRF alone (Patients with 1st FBS $126-180 \mathrm{mg} / \mathrm{dl}$ )

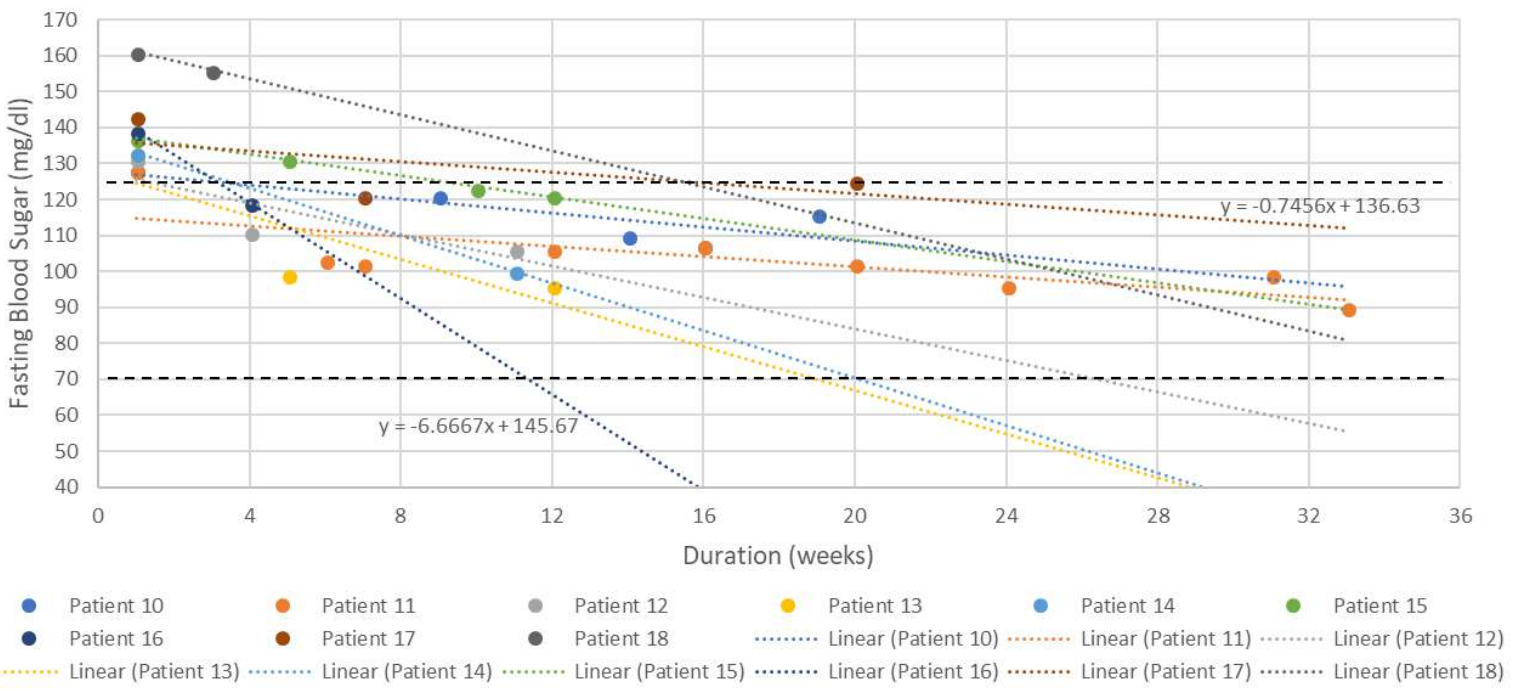


R.D.S.S. Wickramasinghe et al / Beneficial Effects Of Non-Chemically Grown Traditional.....

\section{Graph 06}

FBS following NGTRF alone (Patients with 1st FBS $>180 \mathrm{mg} / \mathrm{dl}$ )

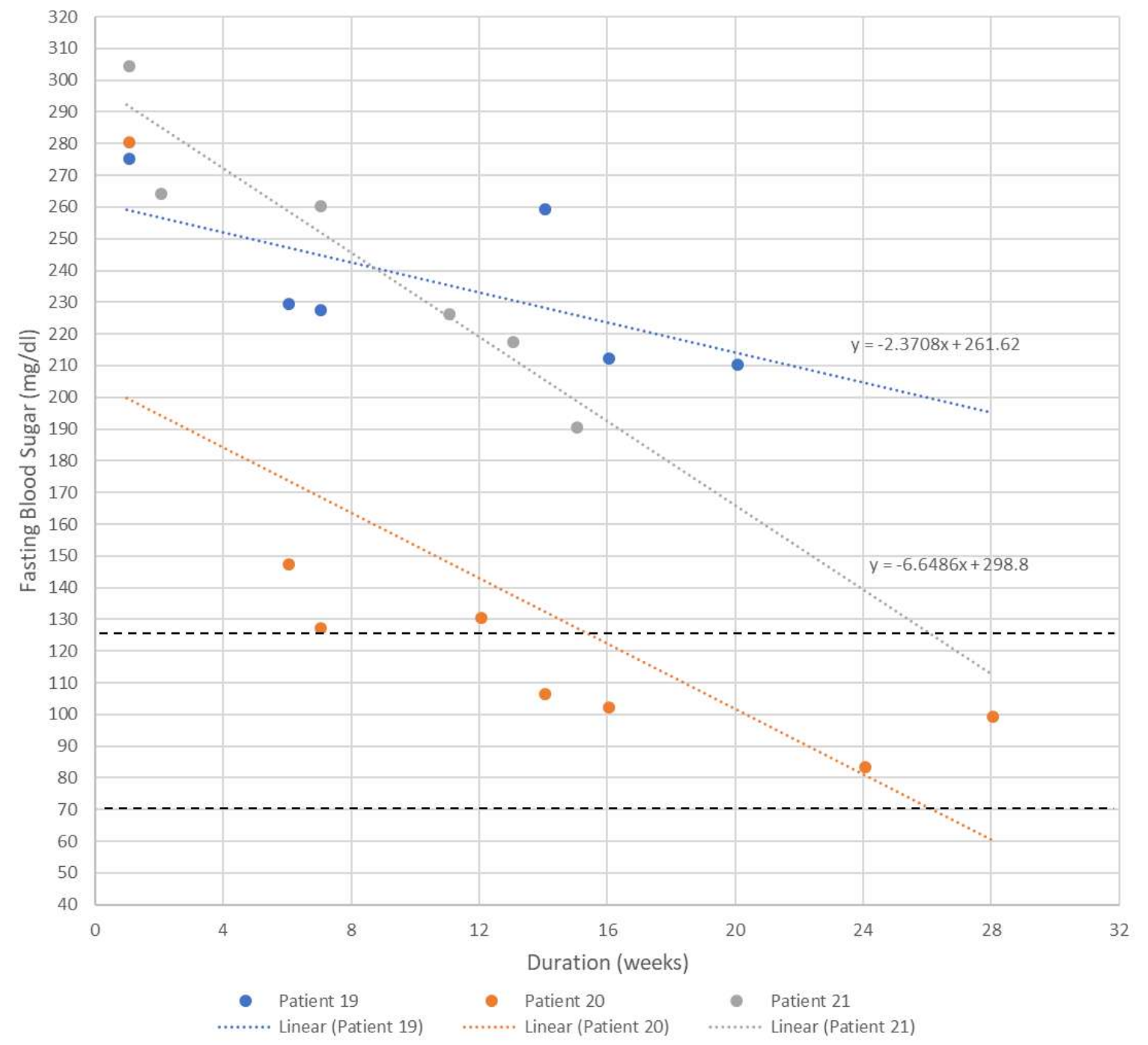


Diabetic/prediabetic Patients who were treated with RWM+NGTRF (Graph 07-12)

Majority of the diabetic patients in Galle $(80.65 \%)$ and Gampaha $(93.75 \%)$ clinics who are on NGTRF+RWM, whose FBS ranged from $110 \mathrm{mg} / \mathrm{dl}$ to $390 \mathrm{mg} / \mathrm{dl}$ at their first clinic visit were found to have improved their glycemic status compared to the initial value. In this treatment category, some patients seem to be shifted towards the hypoglycemic status (less than $70 \mathrm{mg} / \mathrm{dl}$ ).

Results summary of patients of category 1- 4 is shown in Table 03.

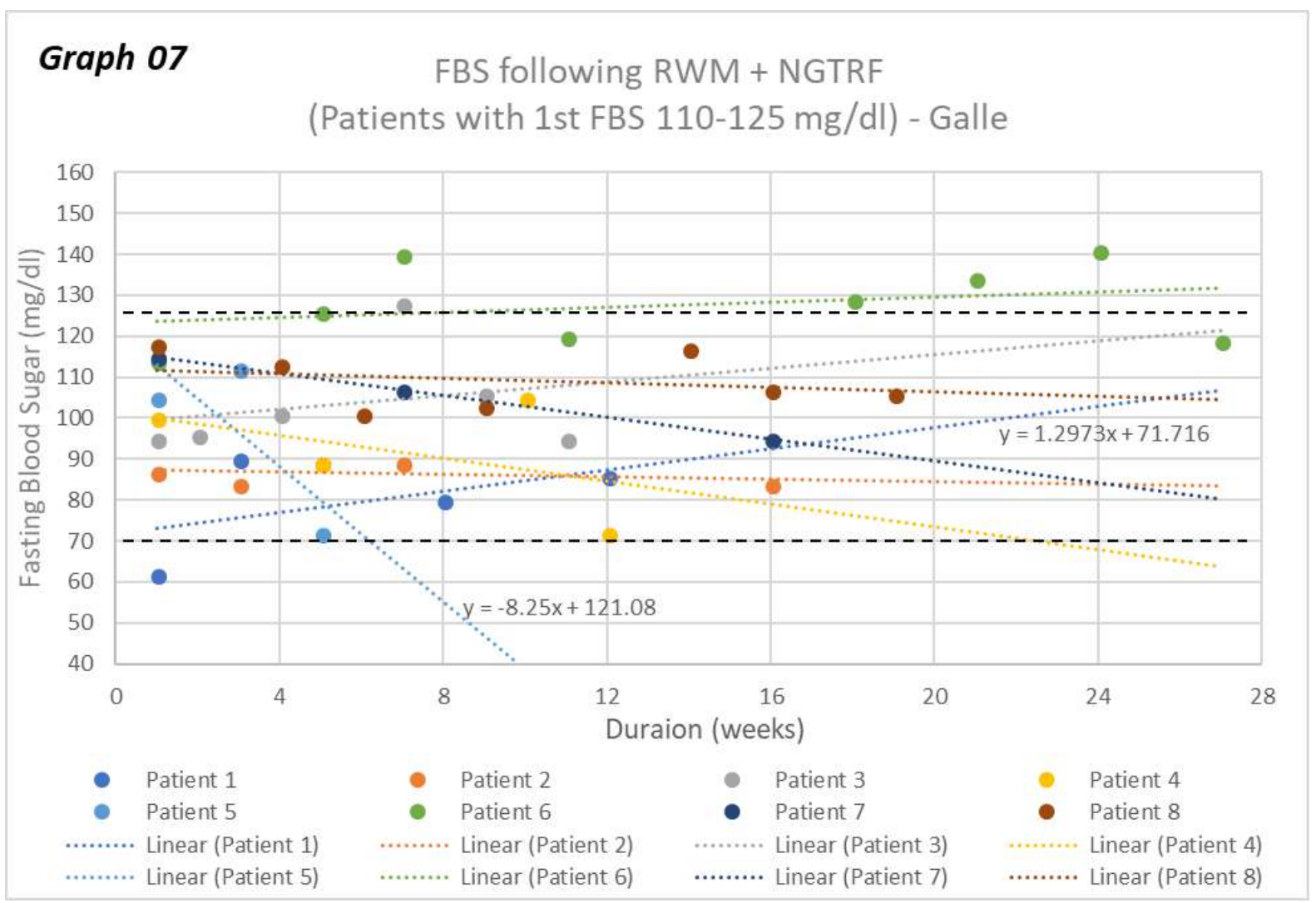




\section{Graph 08}

FBS following RWM + NGTRF

(Patients with 1st FBS 126-180 mg/dl) - Galle

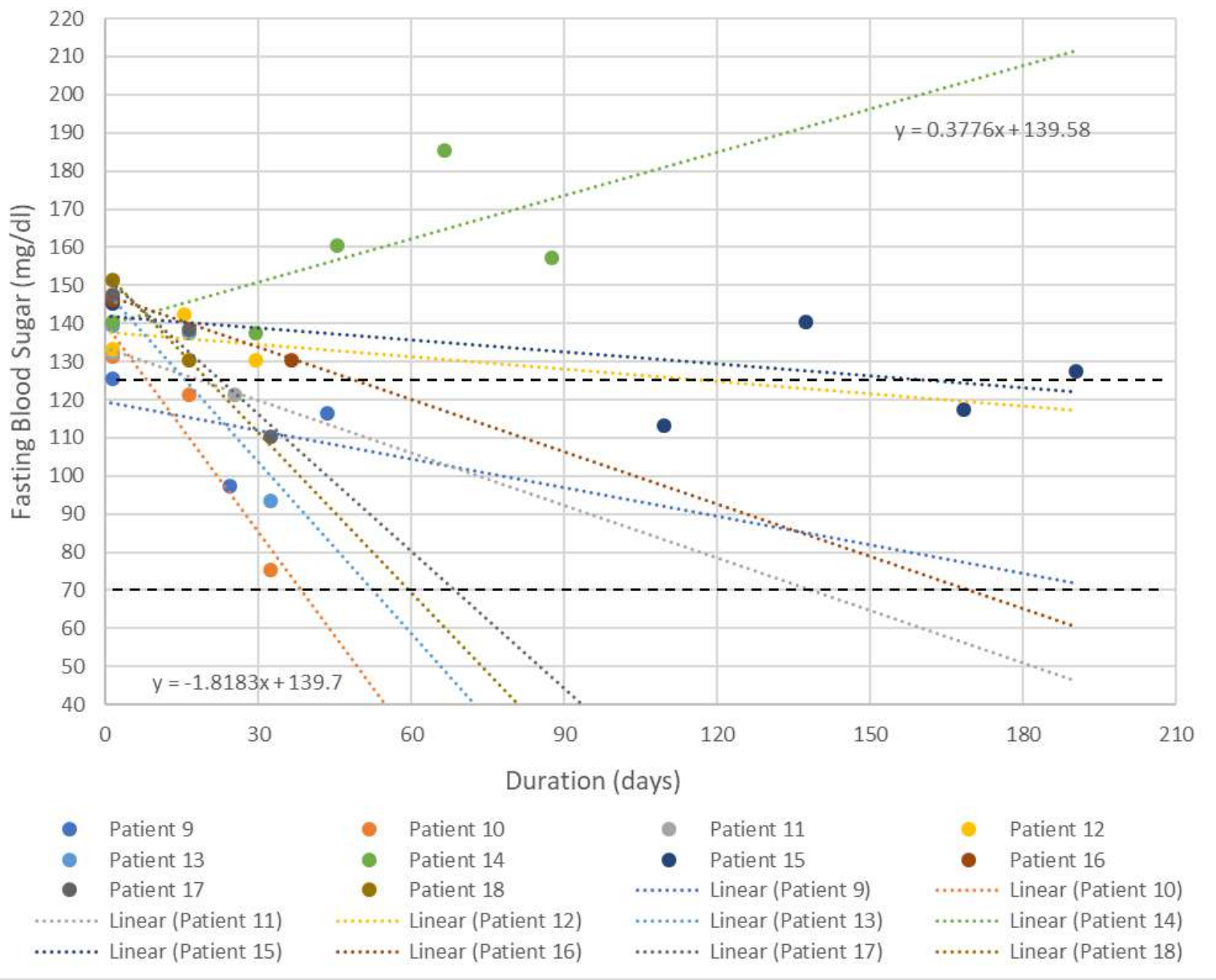


Proceedings of the International Conference on Nutritional and Genetic Epidemiology, Vol. 1, 2017, pp. 20-47

\section{Graph 09}

FBS following RWM + NGTRF

(Patients with 1st FBS >180 mg/dl) - Galle

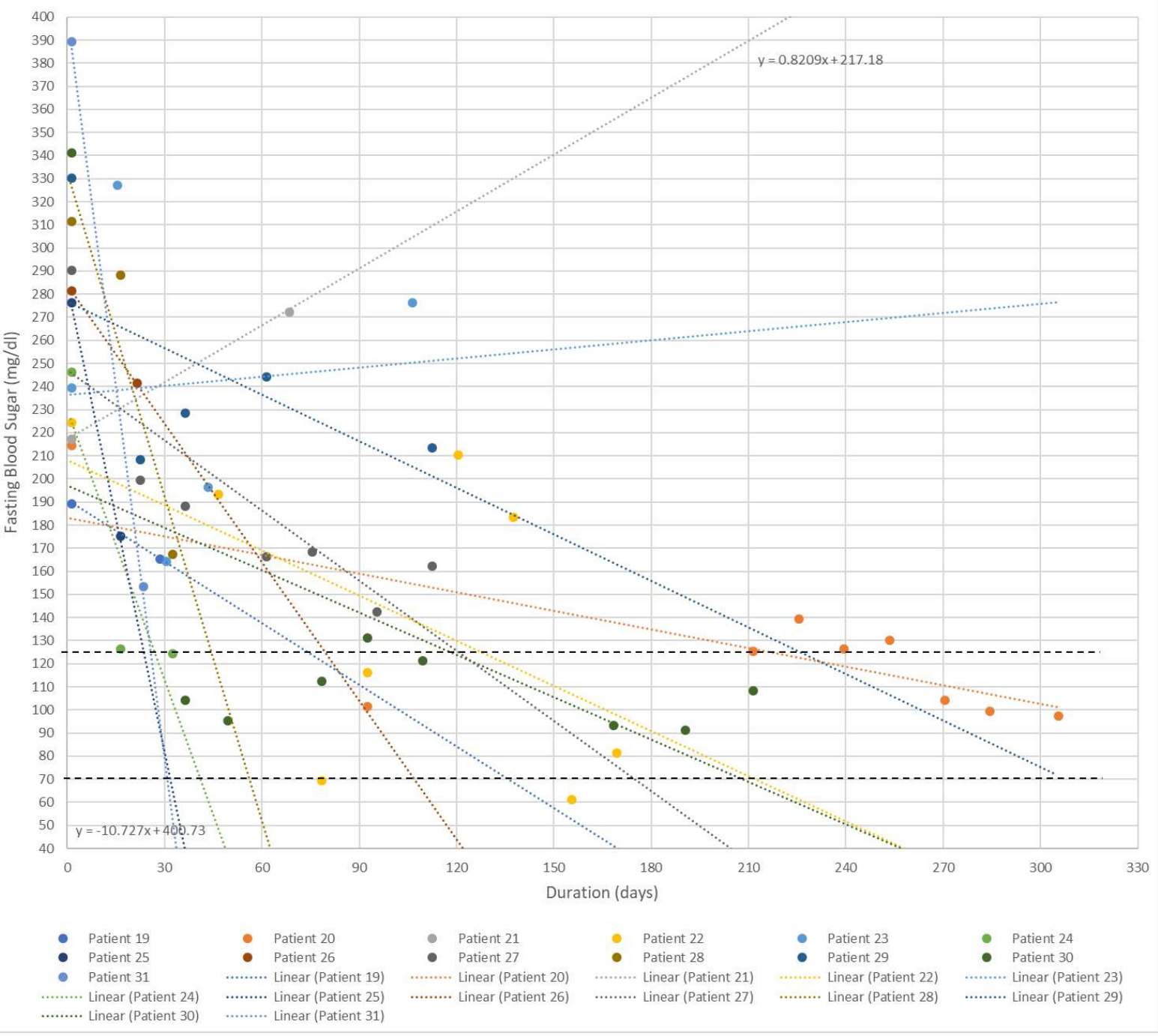




\section{Graph 10}

FBS following RWM + NGTRF

(Patients with 1st FBS 110-125 mg/dl) - Gampaha

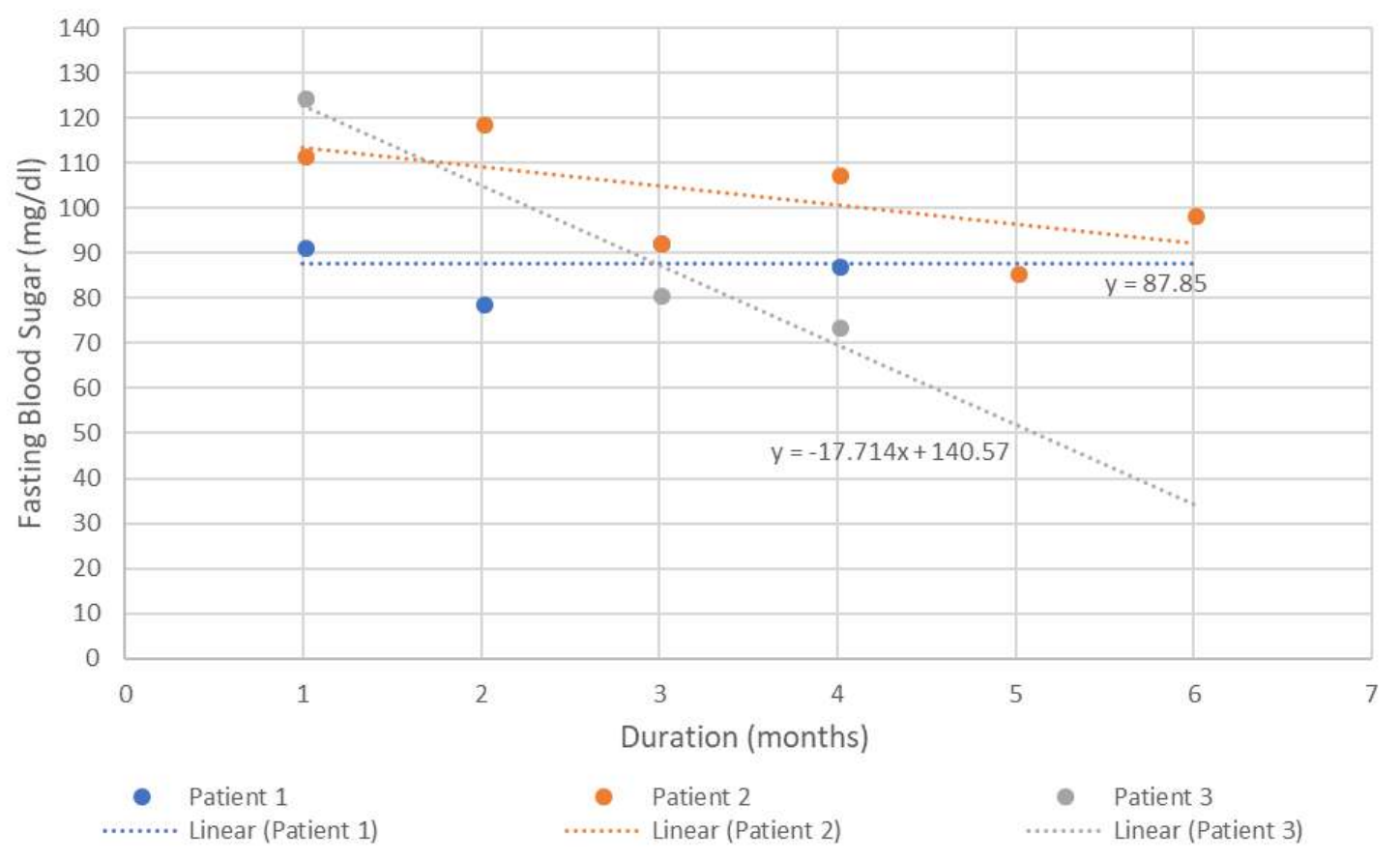

Graph 11

FBS following RWM + NGTRF

(Patients with 1st FBS 126-180 mg/dl) - Gampaha

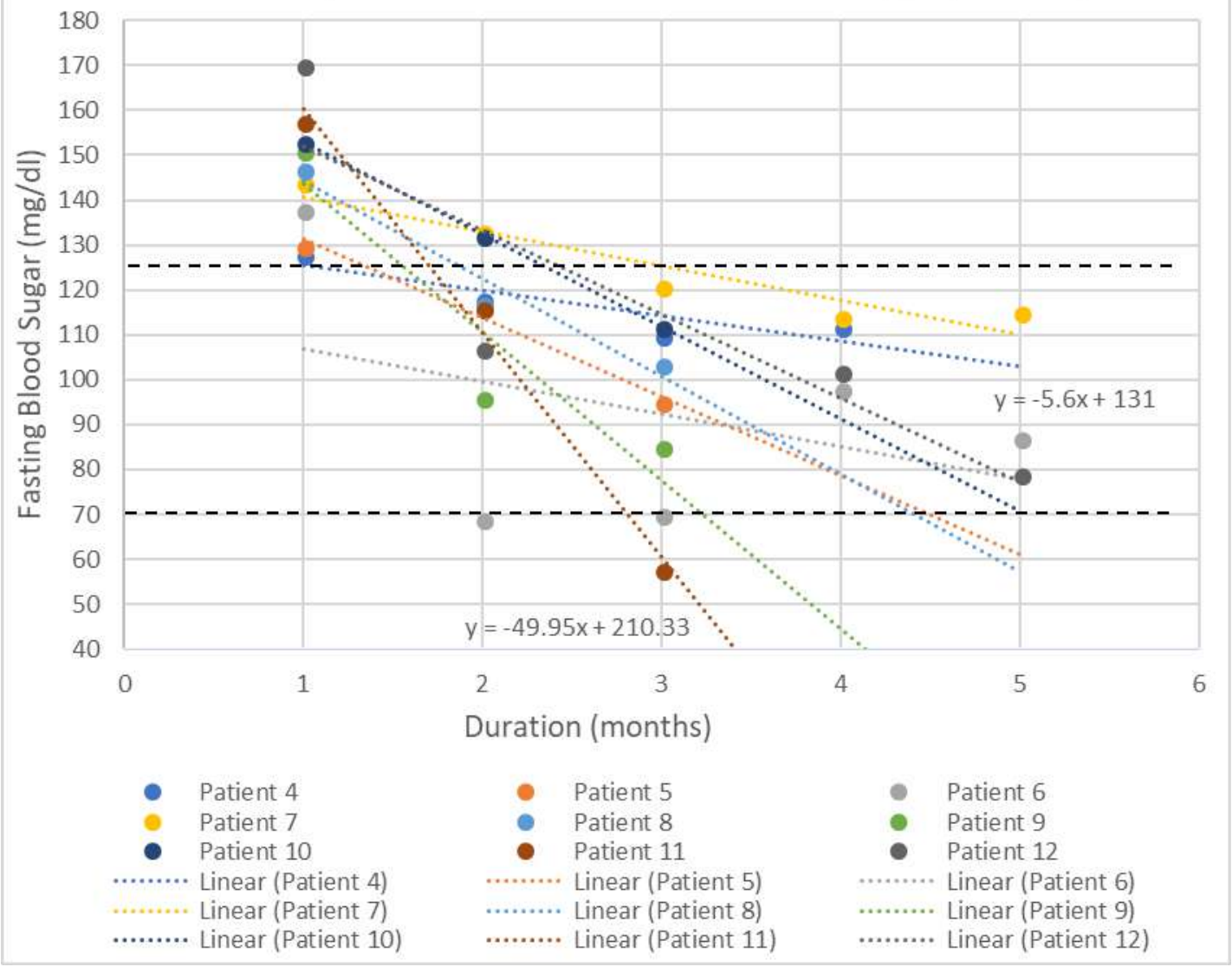




\section{Graph 12}

FBS following RWM + NGTRF

(Patients with 1st FBS >180 mg/dl) - Gampaha

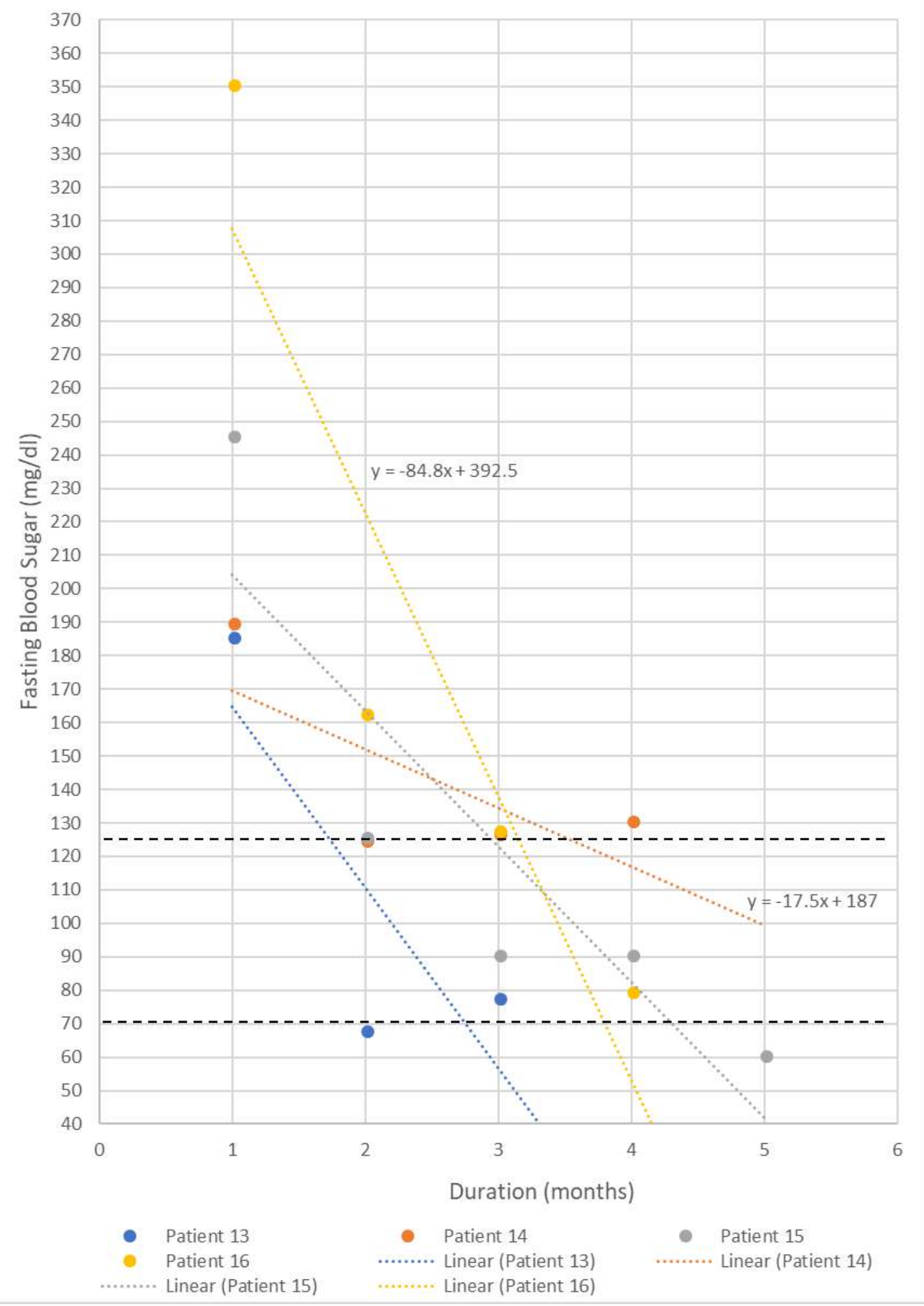


Table 03: Results summary of patients - FBS status of 1-4 treatment categories.

\begin{tabular}{|c|c|c|c|c|c|c|c|}
\hline No & $\begin{array}{l}\text { Treatment } \\
\text { category }\end{array}$ & $\begin{array}{l}\text { No } \\
\text { of } \\
\text { Pts }\end{array}$ & $\begin{array}{l}\text { Initial FBS } \\
\text { Status } \\
\mathrm{mg} / \mathrm{dl}\end{array}$ & $\begin{array}{l}\text { Improved } \\
\text { Count }(\%)\end{array}$ & $\begin{array}{l}\text { Static } \\
\text { Count }(\%)\end{array}$ & $\begin{array}{l}\text { Deteriorated } \\
\text { Count }(\%)\end{array}$ & $\begin{array}{l}\text { Trend range } \\
\mathrm{mg} / \mathrm{dl} / \text { month }\end{array}$ \\
\hline \multirow[t]{4}{*}{01} & \multirow[t]{3}{*}{ RWM alone } & 08 & $110-125$ & 00 & 00 & $08(100 \%)$ & 0.5 to 39.357 \\
\hline & & 08 & $126-180$ & $04(50 \%)$ & 00 & $04(50 \%)$ & -19 to 13.5 \\
\hline & & 12 & $>180$ & $10(83.33 \%)$ & 00 & $02(16.66)$ & -66 to 17.2 \\
\hline & Total & 28 & & $14(50 \%)$ & $00(0 \%)$ & $14(50 \%)$ & \\
\hline \multirow[t]{4}{*}{02} & \multirow[t]{3}{*}{ NGTRF alone } & 09 & $110-125$ & $07(77.78 \%)$ & 01 & 01 & -24.8 to 1.478 \\
\hline & & 09 & $126-180$ & $09(100 \%)$ & 00 & 00 & -26.668, to -2.9824 \\
\hline & & 03 & $>180$ & $03(100 \%)$ & 00 & 00 & -26.5944 to -9.4832 \\
\hline & Total & 21 & & $19(90.47 \%)$ & $01(4.765 \%)$ & $01(4.765 \%)$ & \\
\hline \multirow[t]{4}{*}{03} & \multirow{3}{*}{$\begin{array}{l}\text { RWM+NGTRF } \\
\text { (Galle) }\end{array}$} & 08 & $110-125$ & 05 & 00 & 03 & -8.25 to 1.2973 \\
\hline & & 10 & $126-180$ & 09 & 00 & 01 & -54.549 to 11.328 \\
\hline & & 13 & $>180$ & 11 & 00 & 02 & -321.81 to 24.627 \\
\hline & Total & 31 & & $25(80.65 \%)$ & $00(0 \%)$ & $06(19.35 \%)$ & \\
\hline \multirow[t]{4}{*}{04} & \multirow{3}{*}{$\begin{array}{l}\text { RWM+NGTRF } \\
\text { (Gampaha) }\end{array}$} & 3 & $110-126$ & 02 & 00 & 01 & -17.714 to 87.85 \\
\hline & & 09 & $126-180$ & 09 & 00 & 00 & -49.95 to -5.6 \\
\hline & & 04 & $>180$ & 04 & 00 & 00 & -84.8 to -14.5 \\
\hline & Total & 16 & & $15(93.75 \%)$ & $00(0 \%)$ & $01(6.25 \%)$ & \\
\hline
\end{tabular}

\section{Diabetic/prediabetic Patients who were treated with RWM+NGTRF+HNW (Graph no. 13)}

All the patients had improved diabetic state with reduced FBS and antidiabetic drugs could be gradually reduced or even omitted in most of the patients.

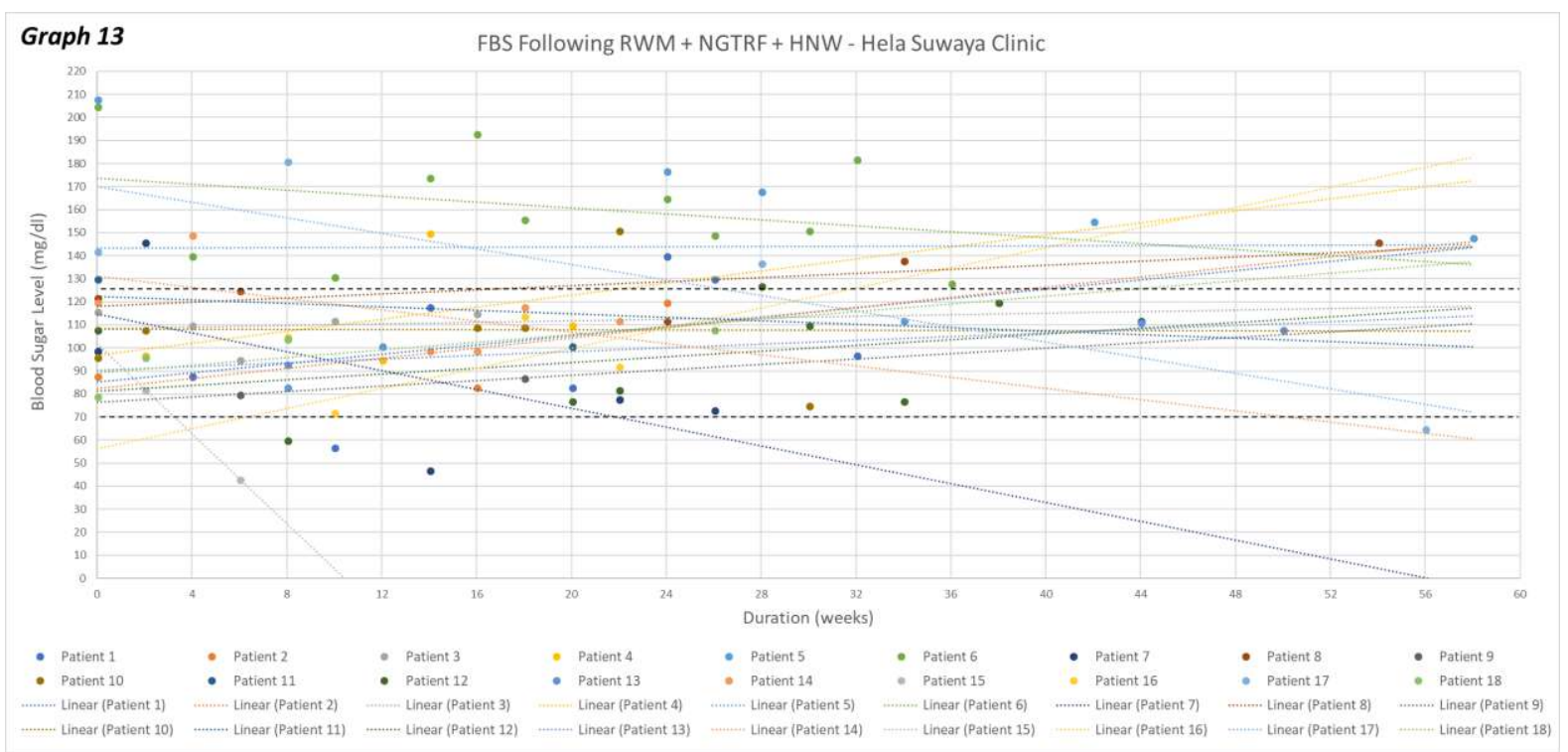




\section{Discussion}

\section{Therapeutic benefits of NGTRF on NAFLD}

Preliminary evidence has shown that fatty liver status was either cured or improving in all the patients. No proven pharmacological or specific food-based intervention has yet been described either to cure, prevent or even to control NAFLD in conventional allopathic medical practice. Though several studies have attempted at finding the therapeutic benefits of Metformin or Vitamin $\mathrm{E}$ in the management of NAFLD, neither of them was found superior to placebo (Lavine et al., 2011). Irrespective of whether the NAFLD is associated with other NCDs or not and on RWM or not, NGTRF is noted to be of therapeutic benefit for the NAFLD. The way traditional food base formulae act upon the NAFLD will be discussed as follows.

\section{Therapeutic benefits of NGTRF on Diabetes}

According to the data maximum therapeutic potential is seen in patients (17 diabetic and 01 prediabetic) who have undergone the treatment category No.05 where both NGTRF and HNW were prescribed while altering the RWM. All the patients were reported reducing trends of FBS and reduction or even omission of the RWM were done in all the patients. Second highest therapeutic potential was reported in treatment category No.04, where they are given NGTRF at the Medical Nutrition Clinic while RWM was prescribed and followed up at Hospital diabetic clinic. Ninety three percent $(93.75 \%)$ of the patients were seen to be having reduced FBS. Third best therapeutic outcome was achieved in the treatment category No.02 in which patients were given only NGTRF. Amongst them $90.47 \%$ had reduced FBS. Fourth best glycemic control was reported (80.65\%) in patients who were managed as treatment category No.03. (where they were given NGTRF while they are on RWM) It was same in the case of category No.04. Patients who had received only RWM were shown the least therapeutic potential i.e. $50 \%$. It should be highlighted that when NGTRF is coupled with antidiabetic drugs or when antidiabetic drugs are given alone there was a clear risk of patients going in to the state hypoglycemia which was evidently seen both symptomatically and by low FBS. Interestingly, hypoglycemia was not seen in the treatment category No.02 where NGTRF was given as the sole treatment. All those patients were maintained within the desired glycemic range without the risk of hypoglycemia.

Clear percentage outcome cannot be expressed in category No.05 with FBS alone as it was complicated by reductions of antidiabetic drugs had to be done along with the treatment. Therefore, the fact of reductions of RWM was also taken in to consideration instead of taking FBS alone as per the comparison of therapeutic outcome in this particular category. The exposure to combined effect of RWM+NGTRF+HNW treatments at the initial stages was able to initiate a metabolic pathway paving way to the dramatic reductions of blood sugar levels. During first 3 months of study, such dramatic reduction is observed in blood sugar levels of most patients causing three of them going in to hypoglycemic state. Diabetes being a progressive disease (according to the western medicine), uncontrollable, rapid rise of FBS is a well-established fact, when the western antidiabetic drugs are reduced/taken off from patients, specially who receive insulin treatment as the final resort. Within the study group, increase of FBS levels are not that substantial compared to the situation which would arise when drugs are being reduced/taken off from patients of similar circumstances.

The fact that 15 out of 18 patient's FBS levels were maintained within desirable range, even when the western antidiabetic drugs have been partially, or completely withdrawn and diabetic diet was not prescribed, shows NGTRF+HNW combination therapy is effective in management of Type 2 diabetes. This fact was further suggested by $98 \%$ improvement of the clinical features in this category compared to $85 \%$ of category no 2 and $73 \%$ of category no 3 and 4 . 


\section{Proposed mechanism of Liver impairment leading to NAFLD and NCD}

Liver is the first organ to be exposed to Nutrients and xenobiotics of dietary origin owing to its situation within a unique circulation called enterohepatic circulation. It acts as the principal organ of detoxification or biotransformation of toxins. Detoxification process of the liver is carried out by a specialized enzyme system called Cytochrome P 450 (CYP), through separate but interrelated steps called phase I (transformation), Phase II (conjugation) and Phase III (transportation) till the final 'non-toxic' product is generated. The product is then excreted through urine, bile or faeces. Metabolizable toxins includes agrochemicals, heavy metals, food additives, drugs, alcohol, microorganisms and other pollutants etc. Presently vast number of xenobiotics, especially agrochemicals are entering in to the body mainly through food, water and air. Enzymatic reactions involving detoxification of all these xenobiotics are nutrient dependent. CYP requires the adequate availability of many vitamins including B and folic acid and phytochemicals like flavonoids to be functioning as coenzymes, co-factors etc. for its transformation reactions such as oxidation, reduction, hydrolysis, hydrogenation etc. Reactive oxygen intermediates thereby produced, requires Glutathione transferases (GSH) and superoxide dismutase(SOD) to prevent their oxidative damage of genes, fat and proteins. Several antioxidant protective nutrients and plant derivatives are essential for activation of these enzymatic pathways. These micronutrients include vitamins A, C and E, and minerals Manganese (Mn), Zinc ( $\mathrm{Zn}$ ), Copper $(\mathrm{Cu})$, Selenium (Se) etc. Mn dependent SODs are also described which minimizes the heavy metal induced oxidative damage. Hela Suwaya proposes that the micronutrient deficiency is the key factor behind the impairment of liver detoxification and thereby the cumulative toxic burden to the hepatocyte, which forms the basis for NAFLD. Deranged hepatocyte function will jeopardize the other metabolic pathways pertaining to the carbohydrate, lipid, endocrine regulation and cause increase predisposition to other NCDs as well.

\section{Micronutrient status of present-day foods and population- the underlying cause proposed by Hela Suwaya}

Hela Suwaya states that present-day population and conventional food are lacking in micronutrients, beneficial microbiota (probiotics) and fibers (prebiotics). Therefore, in similar Sri Lankan setup, 20.9\% of primary school children and $31.6 \%$ of the women of child bearing age were found to be anaemic either due to iron, folate or Vitamin B-12 deficiency. About 29\% of the children below 05 years of age are vitamin A deficient (MOH\&N, 2010). Rest of the micronutrient deficiency states are not or poorly studied in Sri Lanka. According to the data of the research group of Agriculture Research Survey of America in 1997, $\geq 73 \%$ of the American population $(\geq 02$ years of age) are not meeting their 1989 US recommended total daily requirement (TDR) of 12 essential micronutrients (Katherine S. Tippett, 2001). Furthermore, it was recently found that European medicinal diet formulae usually recommended for NCD such as South beach, Atkins, Dash and Best life of are also found to be $78 \%, 56 \%, 49 \%$ and $46 \%$ deficient of micronutrients respectively (Calton, 2010). Therefore, it could generally be considered that micronutrient deficiency is most probably be a global phenomenon irrespective of the economy or advancement of the scientific knowledge in the country.

\section{Scientific basis for Hela Suwaya food based intervention}

According to Hela Suwaya knowledge SLTRV are having very high micronutrient (Vitamin and minaral), Fiber ('Prebiotic' in western science), Benificial microflora ('Probiotic' in western science) and toxin eliminating potential ('Antioxidant activity' according to western science). Therefore, they are ideal food staples for human beings as far as the optimal liver function is concerned. According to the tradional medicinal practice, these rice varieties are of immence nutritional and Medicinal properties and, only very few of them have yet been scientifically proven. The already proven scientific data are worth mentioning here. More than 2000 Traditional/Indigenous rice varieties had been cultivated in ancient Sri Lanka and only around 400 varieties have now been documented. 
Nutrient comparison of SLTRV Vs Modern Rice Varieties(MRV)

Table 04. Scientific Comparison of Nutritional and Medicinal values of SLTRV and MRV

\begin{tabular}{|l|l|l|l|l|l|l|}
\hline \multicolumn{2}{|l|}{ Rice Variety } & $\begin{array}{l}\text { Protein } \\
(\mathrm{mg} \%)\end{array}$ & $\begin{array}{l}\text { Fat } \\
(\mathrm{mg} \%)\end{array}$ & $\begin{array}{l}\text { Carbohydrate } \\
(\mathrm{mg} \%)\end{array}$ & $\begin{array}{l}\text { Iron } \\
(\mathrm{mg} / 100 \mathrm{~g})\end{array}$ & $\begin{array}{l}\text { Antioxidant } \\
\text { Abs/mg ml }\end{array}$ \\
\hline \multirow{5}{*}{} & BG 352 & 7.5 & 4.3 & 72.7 & 0.7 & 1.9 \\
\cline { 2 - 7 } & BG 358 & 6.6 & 2.9 & 73.6 & 0.4 & 1.8 \\
\cline { 2 - 7 } MRV & BG 360 & 7.4 & 2.5 & 72.9 & 0.6 & 1.8 \\
\cline { 2 - 7 } & BG 361 & 6.4 & 2.5 & 76.0 & 1.2 & 2.0 \\
\cline { 2 - 7 } & BG 364 & 10 & 2.9 & 73.7 & 0.4 & 1.7 \\
\cline { 2 - 7 } & AT 307 & 8.6 & 2.7 & 72.7 & 0.4 & 2.1 \\
\cline { 2 - 7 } & AT 354 & 8.4 & 2.4 & 71.9 & 0.8 & 2.0 \\
\hline \multirow{5}{*}{ SLTRV } & Pachchaperumal & 13.3 & 2.8 & 70 & 3.3 & 3.0 \\
\cline { 2 - 7 } & Kalu Heenati & 11.4 & 2.7 & 71 & 2.7 & 2.7 \\
\cline { 2 - 7 } & Kahawanu & 10.6 & 2.7 & 74 & 1.8 & 2.4 \\
\cline { 2 - 7 } & Madathawalu & 11.5 & 3.0 & 71 & 1.7 & 2.8 \\
\cline { 2 - 7 } & Beth Heenati & 11.4 & 2.7 & 73 & 1.7 & 2.2 \\
\cline { 2 - 7 } & Batapolal & 11.1 & 2.5 & 71 & NA & NA \\
\cline { 2 - 7 } & Kuruluthuda & 9.05 & 2.1 & 71 & & 2.4 \\
\hline
\end{tabular}

Source: Industrial Technology Institute, Sri Lanka

Table 05. Comparison of antioxidant activities of SLTRV and MRV

\begin{tabular}{|l|l|l|l|}
\hline \multicolumn{2}{|l|}{ Activity / Compound } & SLTRV & MRV \\
\hline \multirow{2}{*}{ Antioxidant activity (Trolox mmol/100g) } & Total & $8.01-17.88$ & $1.84-1.61$ \\
\cline { 2 - 4 } & Mean & 14.23 & 1.7 \\
\hline \multicolumn{2}{|l}{ Total Proanthocyanidins (mg/g) } & $11.95-21.77$ & 0.0 \\
\hline \multicolumn{2}{|l|}{ Total Phenolic acids (mg/g) } & $16.47-40.43$ & $8.12-8.56$ \\
\hline
\end{tabular}

SLTRV are having high protein content compared to MRV. Most of SLTRV are having protein contents more than $10 \%$ of its weight while that of MRV are less than $10 \%$. Fat and carbohydrate contents are relatively lesser in SLTRV. Iron contents are $>02 \mathrm{mg} / 100 \mathrm{~g}$ and $\leq 02 \%$ in SLTRV and MRV respectively. SLTRV are also having higher fiber content $(>05 \%)$ compared to MRV $(<04 \%)$. SLTRV also have proven bioactivities such as antioxidant, antidiabetic and antiinflammatory activities. Mean antioxidant values of SLTRV are about 08 times that of MRV and anti-inflammatory activity of some SLTRV are several times potent than equivalent amount of allopathic drugs (Premakumara et al., 2013, Abeysekera et al., 2015, Abeysekera et al., 2017). (Table 04,05)

\section{Nutritional and Medicinal value of NGTRF}

It is made up of mixture of four SLTRV such as Pachchaperumal, Padathawaalu, Kahawanu, Kaluheenati etc. (produced by Hela Suwaya toxin free farming technology), mixed together at a specific ratio. It is combined with a special herbal recipe made of mixture of spices, green leaves and herbals taken at a special ratio and processed together with oils. Special spiritual practices are undertaken on production. On cooking, some fresh vegetables such as radish, pumpkin, carrot etc. and coconut milk are added. Hela Suwaya had offered four types of porridge preparations.

Sri Lanka had been once called "spice Island" historically for having the monopoly of her world-renowned spices trade. According to Hela Suwaya, spices are considered rich sources of micronutrients, fibers and beneficial microbiota. Above spices and green leaves have been used since millennia in traditional Sri Lankan culinary practice. They are also scientifically proven to be having bioactivities such as antidiabetic, antidyslipidemic, hepatoprotective, anti-inflammatory, antioxidant activities etc. owing to their rich micronutrient, fiber and phytochemical profile (Farrell, 1999, Pagán, 2017). (Table 06) 
Table 06: Medicinal values of some of the ingredients according to the western scientific literature(Rubio et al., 2013, Prakash and Srinivasan, 2010)

\begin{tabular}{|c|c|c|}
\hline Herbal / Spice & Biological Actions & Phytochemicals \\
\hline $\begin{array}{l}\text { Beli } \\
\text { (Aegle marmelos) }\end{array}$ & $\begin{array}{l}\text { antidiarrheal, antidysenteric, demulcent, antipyretic, } \\
\text { anti-inflammatory, antifungal, radioprotective, } \\
\text { antioxidant }\end{array}$ & $\begin{array}{l}\text { alkaloids (saphonins) flavonoids, glycosides } \\
\text { (tannin), alcohols, aldehydes, aromatic } \\
\text { compounds, fatty acid methylesters, } \\
\text { terpenoids, phenolics, steroids }\end{array}$ \\
\hline $\begin{array}{l}\text { Gammiris } \\
\text { (Piper nigram) }\end{array}$ & $\begin{array}{l}\text { antioxidant, radical scavenging, bioavailability } \\
\text { enhancer of selenium, vitamin B complex, beta- } \\
\text { carotene and curcumin as well as other nutrients, } \\
\text { growth promoter }\end{array}$ & $\begin{array}{l}\text { glutathione peroxidase, glucose-6-phosphate } \\
\text { dehydrogenase, piperine }\end{array}$ \\
\hline $\begin{array}{l}\text { Hāthawāriya } \\
\text { (Asperagus resimosus) }\end{array}$ & $\begin{array}{l}\text { cytotoxic, antitumor activity, antiproliferative, } \\
\text { anxiolytic, antiurolithiatic, ovicidal, larvicidal, } \\
\text { adulticidal, immunostimulant, hepatoprotective }\end{array}$ & \\
\hline $\begin{array}{l}\text { Iramusu } \\
\text { (Hemidesmus indicus) }\end{array}$ & $\begin{array}{l}\text { anticancer, antioxidant, anti-inflammatory, antipyretic, } \\
\text { analgesic, antimicrobial, antidiabetic, hepatoprotective, } \\
\text { cardioprotective, renoprotective, neuroprotective, } \\
\text { immunomodulatory }\end{array}$ & $\begin{array}{l}\text { saponins, tannins, phenols, terpenoids, } \\
\text { flavonoids, coumarins }\end{array}$ \\
\hline $\begin{array}{l}\text { Iriweriya } \\
\text { (Plectranthus zeylanicus) }\end{array}$ & anti-inflammatory & \\
\hline $\begin{array}{l}\text { Kottamalli } \\
\text { (Coriandrum sativum) }\end{array}$ & $\begin{array}{l}\text { antimicrobial, antioxidant, antidiabetic, anxiolytic, } \\
\text { antiepileptic, antidepressant, antimutagenic, anti- } \\
\text { inflammatory, antidyslipidemic, antihypertensive, } \\
\text { neuroprotective, diuretic }\end{array}$ & \\
\hline $\begin{array}{l}\text { Kowakkā } \\
\text { (Cephalandra indica) }\end{array}$ & antidiabetic, anti-urolithic & \\
\hline $\begin{array}{l}\text { Māduru } \\
\text { (Foeniculum vulgare) }\end{array}$ & $\begin{array}{l}\text { renoprotective, phytoestrogene, diuretic, analgesic, } \\
\text { antipyretic, antimicrobial }\end{array}$ & \\
\hline $\begin{array}{l}\text { Neeramulliya } \\
\text { (Asteracantha longifolia) }\end{array}$ & $\begin{array}{l}\text { erythropoietic, antiarthritic, anti tumour, } \\
\text { hepatoprotective, spermatogenetic }\end{array}$ & $\begin{array}{l}\text { flavonoids, terpenoids, steroids, lupeol, } \\
\text { betulin }\end{array}$ \\
\hline $\begin{array}{l}\text { Passion fruit } \\
\text { (Passiflora edulis) }\end{array}$ & antioxidant & phenolics \\
\hline $\begin{array}{l}\text { Polpalā } \\
\text { (Aerva lanata) }\end{array}$ & $\begin{array}{l}\text { antioxidant, anticancer, nephroprotective, diuretic, anti- } \\
\text { inflammatory, hypoglycemic, antidiabetic, antiparasitic, } \\
\text { antimicrobial, hepetoprotective, anti-urolithiasis, } \\
\text { antiasthmatic, antifertility, hypolipidemic }\end{array}$ & $\begin{array}{l}\text { flavonoids, tannins, terpenes (alpha amyrin, } \\
\text { betulin and beta sitosterol), micronutrients } \\
\text { such as potassium, magnesium, calcium, zinc }\end{array}$ \\
\hline $\begin{array}{l}\text { Sūduru } \\
\text { (Cuminum cyminum) }\end{array}$ & nephroprotective, metal chelating & \\
\hline $\begin{array}{l}\text { Thebu } \\
\text { (Costus speciosus) }\end{array}$ & $\begin{array}{l}\text { anti-inflammatory, analgesic, antipyretic, anticancer, } \\
\text { anti-arthritic, antihyperglycemic, antihyperlipidemic } \\
\text { and antioxidative, antibacterial, antifungal }\end{array}$ & costunolide, eremanthin \\
\hline $\begin{array}{l}\text { Uluhāl } \\
\text { (Trigonella foenum) }\end{array}$ & antidiabetic, diuretic, antioxidant, anticancer & \\
\hline $\begin{array}{l}\text { Undupiyaliya } \\
\text { (Desmodium triflorum) }\end{array}$ & $\begin{array}{l}\text { antioxidant, antiproliferative, analgesic, anti- } \\
\text { inflammatory }\end{array}$ & phenolic, flavonoid \\
\hline $\begin{array}{l}\bar{O} \text { Olu } \\
\text { (Nymphaea) }\end{array}$ & hepatoprotective, antioxidant, antibacterial, antifungal & $\begin{array}{l}\text { flavonoids, phenolics, saponin, quercetin, } \\
\text { gallic acid, catechin }\end{array}$ \\
\hline $\begin{array}{l}\text { Garlic } \\
\text { (Allium sativum) }\end{array}$ & $\begin{array}{l}\text { beneficial effect on heart and metabolic diseases, such } \\
\text { as atherosclerosis, thrombosis, hypertension, dementia, } \\
\text { cancer, diabetes }\end{array}$ & $\begin{array}{l}\text { flavonoids (flavones and quercetins) and } \\
\text { sulfur-containing compounds (allyl-cysteine, } \\
\text { diallyl sulfide, allyl trisulfide }\end{array}$ \\
\hline $\begin{array}{l}\text { Welpenela } \\
\text { (Cardiospermum } \\
\text { halicacabum) }\end{array}$ & $\begin{array}{l}\text { antimicrobial, antifungal, antiparasitic, antidiarrheal, } \\
\text { anxiolytic, antipyretic, anti-inflammatory }\end{array}$ & $\begin{array}{l}\text { flavones, aglycones, triterpenoids, } \\
\text { glycosides, variety of fatty acids, volatile } \\
\text { esters }\end{array}$ \\
\hline
\end{tabular}




\section{Antioxidant and lipid lowering potentials of NGTRF}

Antioxidant activity of cooked (ready to drink) NGTRF is increased by 100-250 times compared to traditional rice alone. The fat contents of the coconut milk used to prepare the NGTRF is reduced by $60-90 \%$ in cooked porridge. (Table 07,08)

Table 07: Antioxidant profile of NGTRF(Senanayake P, 2015)

\begin{tabular}{|l|l|l|l|l|}
\hline \multicolumn{3}{|l|}{ Sample } & \multicolumn{3}{|l|}{ Antioxidant activity } \\
\hline \multirow{2}{*}{ Test Results } & \multicolumn{3}{|l|}{ Radical scavenging activity } \\
\cline { 2 - 5 } Method & TPC & FRAP & ABTS & DPPH \\
\hline HSPF (A) & $15.31+/-0.48$ & $25.75+/-0.61$ & $37.47+/-1.03$ & $16.11+/-0.60$ \\
\hline HSPF (B) & $14.83+/-0.86$ & $21.35+/-1.41$ & $36.94+/-0.53$ & $14.24+/-0.52$ \\
\hline HSPF (C) & $11.36+/-0.36$ & $16.28+/-0.64$ & $24.10+/-1.36$ & $15.47+/-0.48$ \\
\hline HSPF (D) & $1.62+/-0.32$ & ND & $15.54+/-0.198$ & $6.37+/-0.18$ \\
\hline
\end{tabular}

Table 08: Summary of principal nutrient contents of NGTRF (Senanayake P, 2015)

\begin{tabular}{|c|c|c|c|c|c|c|}
\hline \multirow{2}{*}{$\begin{array}{l}\text { Test } \\
\text { parameter }\end{array}$} & \multirow[t]{2}{*}{ Unit } & \multirow[t]{2}{*}{ Test method } & \multicolumn{4}{|l|}{ Results } \\
\hline & & & $\begin{array}{l}\text { NGTRF(A) } \\
\text { (White label) }\end{array}$ & $\begin{array}{l}\text { NGTRF(B) } \\
\text { (Green label) }\end{array}$ & $\begin{array}{l}\text { NGTRF }(C) \\
\text { (Blue label) }\end{array}$ & $\begin{array}{l}\text { NGTRF(D) } \\
\text { (Yellow label) }\end{array}$ \\
\hline Vitamin B 1 & $\mathrm{mg} / 200 \mathrm{ml}$ & $\begin{array}{l}\text { MTLM } \\
\text { In-house method based on } \\
\text { journal of Chromatography } \\
\text { A, } 870 \text { (2000) (IMbJC) }\end{array}$ & 0.1 & Not done & Not done & ND \\
\hline Vitamin B 2 & & do & 1.4. & Not done & Not done & 2.94 \\
\hline Vitamin B 3 & & $\begin{array}{l}\text { ITI- American Organization } \\
\text { of Analytical Chemists } \\
\text { (AOAC), 2000/2006 }\end{array}$ & 12.2 & 7.8. & 10.4 & 8.68 \\
\hline Vitamin B 6 & & do & 1.1 & 1.6 & 2.9 & 10.32 \\
\hline Vitamin B 12 & & $\mathrm{IMbJC}$ & 1.4 & Not done & Not done & ND \\
\hline Beta carotene & & ITI- AOAC,2000/2006 & 70 & 210 & 180 & ND \\
\hline Vitamin E & & $\begin{array}{l}\text { MTLM } \\
\text { Method of analysis for } \\
\text { nutrition labeling, 1993, } \\
\text { method No: } 992.03\end{array}$ & 1.1 & Not done & Not done & ND \\
\hline iron & & ITI- AOAC,2000/2006 & 1.05 & 1.08 & 0.85 & 1.66 \\
\hline Zinc & & & 0.36 & 0.46 & 0.26 & 1.08 \\
\hline Calcium & & & 10.54 & 10.48 & 8.0 & 26.8 \\
\hline manganese & & $\begin{array}{l}\text { microwave } \\
\text { dicestion/As/Flame }\end{array}$ & ND & ND & ND & 1.9 \\
\hline Dietary Fiber & & digestion/AAS/Flame & 1.4 & 1.45 & 1.2 & 0.8 \\
\hline Fat & $\mathrm{gr} / 200 \mathrm{ml}$ & ITI- AOAC,2000/2006 & 6.44 & 7.14 & 1.46 & 11.0 \\
\hline Carbohydrate & & & 10.32 & 11.55 & 55.9 & 4.8 \\
\hline Protein & & & 2.03 & 2.24 & 1.39 & 2.42 \\
\hline Minerals & & & 1.85 & 1.88 & 1.85 & ND \\
\hline
\end{tabular}




\section{Vitamin B12 in NGTRF}

It is an essential vitamin for production of blood. Deficiency of Vitamin B12 causes anemia. It is commonly available in animal food such as beef, liver, egg, milk and cheese. But $200 \mathrm{ml}$ cup of this porridge contains Vitamin B12 100\% TDR of a child, though it is $100 \%$ vegetarian. Therefore, this porridge act as a complete source of Vitamin B12 for vegetarians and vegans. (Table 08,09)

Table 09: Nutritional properties and TDR fulfilment with one cup (200 ml) of NGTRF (Senanayake P, 2015)

\begin{tabular}{|l|l|l|}
\hline No & Nutrient & $\%$ Fulfilment of Total daily requirement (TDR) \\
\hline 1 & Vitamin B-2, B-3, B-6 and B-12 & $100 \%$ \\
\hline 2 & Vitamin B-1 & $66 \%$ \\
\hline 3 & Vitamin E & $66 \%$ \\
\hline 4 & Fibers & $25 \%$ \\
\hline 5 & Protein & $12 \%$ \\
\hline 6 & Vitamin A & $10 \%$ \\
\hline 7 & Iron & Considerable amounts \\
\hline 8 & Manganese & Considerable amounts \\
\hline 9 & Zinc & Considerable amounts \\
\hline 10 & Calcium & Considerable amounts \\
\hline 11 & Vitamin D & Considerable amounts \\
\hline
\end{tabular}

\section{“Hela Suwaya" indigenous knowledge about porridge}

According to the "Hela Suwaya" knowledge, porridge preparations are special medicinal diet preparations practiced in "Hela Nila Wedakama", pertaining to Traditional Buddhist Medical Practice. These porridge preparations are usually either rice or other cereal grain based and are added according to a special formula to suite different health needs.

One of the functions of the porridge is to eliminate toxins from the body. The toxins include agrochemical toxins contaminated with food or inherent toxins of the food, which are formed as a result of the different environmental conditions (red fraction of light) and genetic alterations of the food (eg. Genetically modified organisms). Regulation of the hormonal and enzymatic balance of the body is achieved through optimization of micronutrients, fibers and essential microbiota. Therefore, these types of porridges are of immense benefit to the present-day consumers, as they eat contaminated food, owing to intense agricultural practices. Furthermore, almost all the traditional foods varieties are now almost eradicated due to intense agricultural practices (improving, hybridization or Genetic modification). To the best of our knowledge, literature pertaining to this area is very much scares and SLTRV based porridges and their clinical effects are either minimally or not studied scientifically. Western nutritionists believe that the resulting consumption of modified food varieties creates a mismatch between genetic composition of food and ancestral human genetic material causing the "evolutionary discordance", the basis for rapidly rising Non-communicable diseases.

\section{Concept of "Functional food"}

According to western science, foods which have additional Nutritional and medicinal properties compared to an ordinary food are called functional foods. They are prescribed for special medicinal and nutritional requirements. Usually, they are highly expensive special diet Formulae in local and overseas markets. Therefore, SLTRV and NGTRF are "Functional food" which are socio-economically acceptable in Sri Lankan context. 


\section{Spiritual value of TRV and Porridge}

SLTRV are considered "Buddha Bhoga", i.e. the food staples were highly valued by Lord Buddha, as the most suitable foods for mankind, which facilitates both physical as well as spiritual health. Porridges are one of the food preparations commonly offered to Lord Buddha. Lord Buddha had described and highly appreciated about medicinal values of the porridge in "Yãgu Suththa".

\section{Comparison of therapeutic principles of allopathic medicine and Hela Suwaya treatment}

According to the allopathic medicine, eight principal pathophysiological mechanisms have been identified as the basis for DM. They are called an "ominous octet". They are (i) reduction of insulin secretion from pancreatic $\beta$ cells, (ii) increased secretion of glucagon from $\alpha$ cells of the pancreas (iii) enhanced production of glucose in the liver (iv) insulin resistance of the brain coupled with neurotransmitter dysfunction (v) increased lipolysis (vi) enhanced renal glucose reabsorption (vii) reduction of the incretin effect of the small intestine and (viii) reduced or diminished glucose uptake by peripheral tissues such as skeletal muscle, liver and adipose tissues. RWM, aims at selective modification of the mechanisms of "ominous octet" through artificially produced pharmacological agents. They are usually mono-compound drug such as biguanides, sulfonylureas, insulin etc. (Chaudhury et al., 2017)

According to the Hela Suwaya knowledge pertaining to diabetic management, NGTRF, which are naturally processed whole food, targeted at balancing the entire system including gut, liver and endocrine system through optimization of,

- food digestion, micronutrient production, detoxification and nutrient absorption in the gut and

- liver function through facilitating the metabolism of toxins, carbohydrates, lipids etc.

This optimization is basically achieved through minimization of toxin exposure and adequate supply of micronutrients, prebiotics and probiotics by introducing porridges made of traditional rice (spices and green leaves etc.) which were produced through toxin free farming. Therefore, instead of targeting individual mechanisms, what Hela Suwaya planned was to achieve wholistic intervention through introducing traditional toxin free dietary habit among patients. NGTRF is such a naturally processed traditional whole food with a balanced micronutrient, prebiotic and probiotic status.

At this point, Hela Suwaya elaborates the difference between using antidiabetic drugs (Mono-compounds) as opposed to using NGTRF (a whole food) in the management of NCD including diabetes and NAFLD. In category No.01 where RWM alone was used had to gradually increase the dose with time due to increasing FBS in $50 \%$ of patients. When it was coupled with NGTRF (category no.3, 4 and 5) the glycaemic control is well achieved, but there is a risk of patients running in to hypoglycaemia. This is thought to be due to the selective action of mono-compound antidiabetic drugs in addition to balanced state created by the NGTRF. This fact was further confirmed by the fact that when NGTRF alone is used optimized glycemic control had been achieved in $90 \%$ with no risk of hypoglycaemia.

Furthermore, it was seen that still around $10 \%$ of the patients were unable to be controlled or refractory with category no. 2, 3 and 4 treatment models. Therefore, $100 \%$ therapeutic beneficial achievement was fulfilled when the HNW had also been introduced in addition to the other treatment modes, which aims at regularization/balancing of endocrine system through herbal application on specific active points on the skin called "Nila" points. The scientific proof of actual therapeutic benefit of HNW alone will be dealt with in future studies. 


\section{Conclusion}

Preliminary evidence shows that complimentary or sole therapy with NGTRF has significant long-term positive impact on NAFLD and Diabetes compared to RWM alone. Best outcome is achieved when HNW is coupled. Controlled clinical trials are being designed for further proof.

\section{Ethical and administrative considerations}

We have obtained informed consent from the patients, guardians and directors of hospitals to be published.

\section{Acknowledgments}

The authors acknowledge the God Natha and God Vipassaka for giving the technology of Hela Nila Wedakama and Hela Govithena and for all the guidance.

\section{References}

Abeysekera, W. K. S. M., Arachchige, S. P. G., Ratnasooriya, W. D., Choudhary, M. I., Dalvandi, K. \& Chandrasekharan, N. V. 2015. Anti-diabetic Related Health Food Properties of Traditional Rice (Oryza sativa L.) in Sri Lanka. Journal of Coastal Life Medicine, 3, 815-820.

Abeysekera, W. K. S. M., Premakumara, G. A. S., Bentota, A. P. \& Abeysiriwardena, D. S. D. Z. 2017. Grain Amylose Content and its Stability over Seasons in a Selected Set of Rice Varieties Grown in Sri Lanka. Journal of Agricultural Sciences, 12.

Acharya, M. 2013. Food Micro-nutrients \& Organic (Natural) Farming. International Journal of Agriculture and Food Science Technology, 4, 379-384.

ALF. 2017. Non-Alcoholic Fatty Liver Disease [Online]. American Liver Foundation. Available: https://www.liverfoundation.org/for-patients/non-alcoholic-fatty-liver-disease/\#150344805317191d6dfde-16ec [Accessed 12th October 2017].

Amarapurkar, D. N., Hashimoto, E., Lesmana, L. A., Sollano, J. D., Chen, P. J., Goh, K. L. \& Asia-Pacific Working Party On, N. 2007. How common is non-alcoholic fatty liver disease in the Asia-Pacific region and are there local differences? J Gastroenterol Hepatol, 22, 788-93.

Bergman, C. K. 2017. The 3 phases of liver detoxification and what it means for you [Online]. Available: http://kelwayhealth.com/3-phases-liver-detoxification/ [Accessed 17th September 2017].

Calton, J. B. 2010. Prevalence of micronutrient deficiency in popular diet plans. J Int Soc Sports Nutr, 7, 24.

Canbay, A., Bechmann, L. \& Gerken, G. 2007. Lipid Metabolism in the liver. Z Gastroenterol, 45, 35-41.

Chaudhury, A., Duvoor, C., Reddy Dendi, V. S., Kraleti, S., Chada, A., Ravilla, R., Marco, A., Shekhawat, N. S., Montales, M. T., Kuriakose, K., Sasapu, A., Beebe, A., Patil, N., Musham, C. K., Lohani, G. P. \& Mirza, W. 2017. Clinical Review of Antidiabetic Drugs: Implications for Type 2 Diabetes Mellitus Management. Front Endocrinol (Lausanne), 8, 6.

Chavez-Talavera, O., Tailleux, A., Lefebvre, P. \& Staels, B. 2017. Bile Acid Control of Metabolism and Inflammation in Obesity, Type 2 Diabetes, Dyslipidemia, and Nonalcoholic Fatty Liver Disease. Gastroenterology, 152, 1679-1694 e3.

Chen, G. 2015. The link between Hepatic Vitamin A Metabolism and Nonalcoholic Fatty Liver Disease. Curr Drug Targets, 16, 1281-92.

Dearing, M. D. \& Kohl, K. D. 2017. Beyond Fermentation: Other Important Services Provided to Endothermic Herbivores by their Gut Microbiota. Integr Comp Biol, 57, 723-731.

Dillard, C. J. \& German, J. B. 2000. Phytochemicals: nutraceuticals and human health. Journal of the Science of Food and Agriculture, 80, 1744-1756.

Ekstedt, M., Franzen, L. E., Mathiesen, U. L., Thorelius, L., Holmqvist, M., Bodemar, G. \& Kechagias, S. 2006. Long-term follow-up of patients with NAFLD and elevated liver enzymes. Hepatology, 44, 865-73.

Farrell, K. T. 1999. Spices, condiments, and seasonings.

Festi, D., Schiumerini, R., Eusebi, L. H., Marasco, G., Taddia, M. \& Colecchia, A. 2014. Gut microbiota and metabolic syndrome. World J Gastroenterol, 20, 16079-94. 
Fotbolcu, H. \& Zorlu, E. 2016. Nonalcoholic fatty liver disease as a multi-systemic disease. World $J$ Gastroenterol, 22, 4079-90.

Heidari, Z. \& Gharebaghi, A. 2017. Prevalence of Non Alcoholic Fatty Liver Disease and its Association with Diabetic Nephropathy in Patients with Type 2 Diabetes Mellitus. J Clin Diagn Res, 11, OC04-OC07.

Katherine S. Tippett, L. E. C. 2001. Results From USDA's 1994-96 Diet and Health Knowledge Survey. United States Department of Agriculture.

Kim, D. \& Kim, W. R. 2017. Nonobese Fatty Liver Disease. Clin Gastroenterol Hepatol, 15, 474-485.

Klatt, B. K., Holzschuh, A., Westphal, C., Clough, Y., Smit, I., Pawelzik, E. \& Tscharntke, T. 2014. Bee pollination improves crop quality, shelf life and commercial value. Proc Biol Sci, 281, 20132440.

Kosiewicz, M. M., Zirnheld, A. L. \& Alard, P. 2011. Gut microbiota, immunity, and disease: a complex relationship. Front Microbiol, 2, 180.

Lavine, J. E., Schwimmer, J. B., Van Natta, M. L., Molleston, J. P., Murray, K. F., Rosenthal, P., Abrams, S. H., Scheimann, A. O., Sanyal, A. J., Chalasani, N., Tonascia, J., Unalp, A., Clark, J. M., Brunt, E. M., Kleiner, D. E., Hoofnagle, J. H., Robuck, P. R. \& Nonalcoholic Steatohepatitis Clinical Research, N. 2011. Effect of vitamin $\mathrm{E}$ or metformin for treatment of nonalcoholic fatty liver disease in children and adolescents: the TONIC randomized controlled trial. JAMA, 305, 1659-68.

Mann, J. P., Goonetilleke, R. \& Mckiernan, P. 2015. Paediatric non-alcoholic fatty liver disease: a practical overview for non-specialists. Arch Dis Child, 100, 673-7.

Marchesini, G., Brizi, M., Bianchi, G., Tomassetti, S., Bugianesi, E., Lenzi, M., Mccullough, A. J., Natale, S., Forlani, G. \& Melchionda, N. 2001. Nonalcoholic fatty liver disease: a feature of the metabolic syndrome. Diabetes, 50, 1844-50.

MOH\&N 2010. National Nutrition Policy Sri Lanka. Ministry of Healthcare and Nutrition, Democratic Socialist Republic of Sri Lanka.

O'connor, E. M. 2013. The role of gut microbiota in nutritional status. Curr Opin Clin Nutr Metab Care, 16, 509-16.

Pagán, C. N. 2017. Spices and Herbs That Can Help You Stay Healthy [Online]. Available: https://www.webmd.com/healthy-aging/over-50-nutrition-17/spices-and-herbs-health-benefits [Accessed October 2nd 2017].

Parnell, J. A. \& Reimer, R. A. 2012. Prebiotic fiber modulation of the gut microbiota improves risk factors for obesity and the metabolic syndrome. Gut Microbes, 3, 29-34.

Prakash, U. N. \& Srinivasan, K. 2010. Beneficial influence of dietary spices on the ultrastructure and fluidity of the intestinal brush border in rats. Br J Nutr, 104, 31-9.

Premakumara, G. A. S., Abeysekera, W. K. S. M., Ratnasooriya, W. D., Chandrasekharan, N. V. \& Bentota, A. P. 2013. Antioxidant, anti-amylase and anti-glycation potential of brans of some Sri Lankan traditional and improved rice (Oryza sativa L.) varieties. Journal of Cereal Science, 58, 451-456.

Puri, P. \& Sanyal, A. J. 2012. Nonalcoholic fatty liver disease: Definitions, risk factors, and workup. Clinical Liver Disease, 1, 99-103.

Rubio, L., Motilva, M. J. \& Romero, M. P. 2013. Recent advances in biologically active compounds in herbs and spices: a review of the most effective antioxidant and anti-inflammatory active principles. Crit Rev Food Sci Nutr, 53, 943-53.

Senanayake P, S. N., Dahanayake Ks, De Silva Rad 2015. "Hela Suwaya” Special Porridge Formula (HSPF): A timely food based solution for rising Non Communicable Diseases (NCD) in Sri Lanka. First International Conference on Natural Products Genomics and Drug Discovery, 12-13.

Siriwardana, R. C., Niriella, M. A., Liyanage, C. A., Wijesuriya, S. R., Gunathilaka, B., Dassanayake, A. S. \& De Silva, H. J. 2013. Cryptogenic cirrhosis is the leading cause for listing for liver transplantation in Sri Lanka. Indian J Gastroenterol, 32, 397-9.

Sundaram, S. S. 2012. Non-Alcoholic Fatty Liver Disease [Online]. American Liver Foundation. Available: http://ftp.liverfoundation.org/chapters/rockymountain/doctorsnotes/pediatricnafld// [Accessed 10th November 2017].

Tarantino, G. \& Finelli, C. 2013. What about non-alcoholic fatty liver disease as a new criterion to define metabolic syndrome? World J Gastroenterol, 19, 3375-84.

Tidjani Alou, M., Lagier, J.-C. \& Raoult, D. 2016. Diet influence on the gut microbiota and dysbiosis related to nutritional disorders. Human Microbiome Journal, 1, 3-11.

Vassilatou, E., Vassiliadi, D. A., Salambasis, K., Lazaridou, H., Koutsomitopoulos, N., Kelekis, N., Kassanos, D., Hadjidakis, D. \& Dimitriadis, G. 2015. Increased prevalence of polycystic ovary syndrome in premenopausal women with nonalcoholic fatty liver disease. Eur J Endocrinol, 173, 739-47.

Viviane C. Pires1, F. A. S., Edison R. Sujii2, Karoline R. S. Torezani2, Wallyson A. Rodrigues2, Fábio A. Albuquerque3, Sandra M. M. Rodrigues4, Antonieta N. Salomão2 And Carmen S. S. Pires2 2014. Importance of Bee Pollination for Cotton Production in Conventional and Organic Farms in Brazil. Journal of Pollination Ecology, 13, 151-160. 
Webb, D. 2013. Phytochemicals' Role in Good Health. Today's Dietitian, 15, 70.

WHO 2014. Global Status Report on Noncommunicable Diseases 2014. World Health Organization.

Withana, C. 2014. Dietary Guidelines \& Nutrition Therapy for Specific diseases. Nutrition Division - Ministry of Health, Sri Lanka.

Wu, X. \& Tian, Z. 2017. Gut-liver axis: gut microbiota in shaping hepatic innate immunity. Sci China Life Sci, 60, 1191-1196.

Younossi, Z. M., Koenig, A. B., Abdelatif, D., Fazel, Y., Henry, L. \& Wymer, M. 2016. Global epidemiology of nonalcoholic fatty liver disease-Meta-analytic assessment of prevalence, incidence, and outcomes. Hepatology, 64, 73-84.

Zacharia, J. T. 2011. Ecological Effects of Pesticides, University of Dar es Salaam, InTech. 